\title{
1 Species-specific calcite production reveals Coccolithus \\ 2 pelagicus as the key calcifier in the Arctic Ocean
}

\section{Chris J. Daniels ${ }^{\mathbf{a}, \mathbf{b}, 1}$, Alex J. Poulton ${ }^{\mathrm{a}}$, Jeremy R. Young ${ }^{\mathrm{c}}$, Mario Esposito ${ }^{\mathrm{a}}$, \\ 4 Matthew P. Humphreys ${ }^{\text {b }}$, Mariana Ribas-Ribas ${ }^{\text {b,d }}$, Eithne Tynan ${ }^{\text {b }}$ and Toby \\ 5 Tyrrell $^{\mathbf{b}}$.}

6 [a] \{Ocean Biogeochemistry and Ecosystems, National Oceanography Centre, University of

7 Southampton Waterfront Campus, Southampton, SO14 3ZH, United Kingdom\}

8 [b] \{Ocean and Earth Science, National Oceanography Centre Southampton, University of

9 Southampton, Southampton, SO14 3ZH, United Kingdom\}

10 [c] \{University College London, London, WC1E 6BT, United Kingdom\}

11 [d] \{Carl von Ossietzky Universität Oldenburg, Institute for Chemistry and Biology of the

12 Marine Environment, Wilhelmshaven, 26382, Germany\}

131 To whom correspondence should be addressed. Email: c.daniels@noc.ac.uk

Author contributions: C.J.D and A.J.P designed the research; C.J.D., A.J.P., J.R.Y., M.E., M.P.H., M.R-R., and E.T. performed research; C.J.D. and A.J.P. analysed data; and C.J.D. wrote the paper, with input from all co-authors.

21 Running Head: Coccolithus pelagicus dominates Arctic Ocean calcification

22 Key Words: Coccolithophores; Calcification; Arctic Ocean. 


\section{Abstract}

24 Through the production and export of their calcite coccoliths, coccolithophores form a key component of the global carbon cycle. Despite this key role, very little is known about the biogeochemical role of different coccolithophore species in terms of calcite production, and

27 how these species will respond to future climate change and ocean acidification. Here we

28 present the first study to determine species-specific calcite production, from samples

29 collected in the Arctic Ocean and subarctic Iceland Basin in June 2012. We show that

30 although the coccolithophorid Coccolithus pelagicus comprised only a small fraction of the total community in terms of abundance ( $2 \%$ ), it was the major calcite producer in the Arctic

32 Ocean and Iceland Basin (57 \% of total calcite production). In contrast, Emiliania huxleyi

33 formed $27 \%$ of the total abundance and was responsible for only $20 \%$ of the calcite

34 production. That $C$. pelagicus was able to dominate calcite production was due to its

35 relatively high cellular calcite content compared with the other species present. Our results

36 demonstrate for the first time the importance of considering the complete coccolithophore

37 community when considering pelagic calcite production, as relatively rare but heavily

38 calcified species such as C. pelagicus can be the key calcite producers in mixed communities.

39 The response of $C$. pelagicus to ocean acidification and climate change is therefore likely to have a major impact on carbon cycling within the North Atlantic and Arctic Ocean. 
43 Coccolithophores are a major group of phytoplankton, comprising up to $10 \%$ of primary

44 production (Poulton et al. 2007), dominating pelagic calcite production and export with their calcite coccoliths (Broecker \& Clark 2009), and thus forming a key component of the global carbon cycle (de Vargas et al. 2007, Ziveri et al. 2007). Marine calcifiers, including coccolithophores, face an uncertain future, as they have to contend with the effects of global warming and ocean acidification (Royal Society 2005, Winter et al. 2013). Culture experiments considering the response of coccolithophores to ocean acidification have produced conflicting results (Iglesias-Rodriguez et al. 2008, Langer et al. 2009, Hoppe et al. 2011), with long term studies suggesting adaptive evolution could partly compensate for the effect of global warming and ocean acidification (Lohbeck et al. 2012, Schluter et al. 2014). Furthermore, more mechanistic understanding of coccolithophore responses to variable $\mathrm{pH}$ indicate that different species respond differently (Langer et al. 2009) and have different growth optimum conditions in terms of pH (Bach et al. 2015).

Many of the previous studies on coccolithophores, along with the majority of the current literature, consider only a single species of coccolithophore: Emiliania huxleyi. Although E. huxleyi is considered the keystone coccolithophore species due to its global dominance and ability to form large-scale highly visible blooms (Paasche 2002), there are 200 extant species of coccolithophore, which vary considerably in cell size (2 to $20 \mu \mathrm{m}$ ), and cellular calcite quota (Young et al. 2003). In this context, E. huxleyi has a relatively small cell ( 5 $\mu \mathrm{m})$ with a relatively low cellular calcite content $\left(0.2-1.1 \mu \mathrm{mol} \mathrm{C}\right.$ cell $^{-1}$; Paasche 2002, Daniels et al. 2014) and hence relatively low calcification rates; other larger and more heavily calcified species, such as Coccolithus pelagicus with $~ 30$ times more calcite per cell than $E$. huxleyi (Daniels et al. 2014), have the potential to be key species in terms of upper ocean calcite production and export (Ziveri et al. 2000, Bauman et al. 2004, Daniels et al. 2014). The response of coccolithophores to ocean acidification in culture experiments appears to differ between species and strains (Langer et al. 2006, Langer et al. 2009), and culture experiments do not necessarily reflect the response of natural populations to environmental fluctuations (Smith et al. 2012). Therefore it is unlikely that E. huxleyi’s response to ocean acidification in culture can be applied to multi-species populations of coccolithophores (Bach et al. 2015). In natural communities the response to variability in $\mathrm{pH}$ is often secondary to effects of light, nutrient availability and growth rate (Zondervan 2007, Charalampopoulou et 
respond to environmental changes, and to assess the relative biogeochemical importance of different coccolithophore species, field studies considering the whole coccolithophore community are required.

The effect of anthropogenic $\mathrm{CO}_{2}$ emissions on the Arctic Ocean is expected to be among the largest and most rapid of any region on the globe (ACIA 2004), with the Arctic already experiencing rapid warming (ACIA 2004). Ocean acidification is also expected to be particularly enhanced at high latitudes because of the increased solubility of $\mathrm{CO}_{2}$ at low temperatures. Within the Nordic Seas (Greenland Sea and Norwegian Sea) of the Arctic Ocean large natural gradients of environmental variables such as temperature and carbonate chemistry already exist; in the west, the East-Greenland Current transports cold $\left(<0{ }^{\circ} \mathrm{C}\right)$ Polar Water southwards through the Greenland Sea (Fig. 1), while in the east the Norwegian Current carries relatively warm $\left(6-10^{\circ} \mathrm{C}\right)$ Atlantic water into the Norwegian Sea (Johannessen 1986).

Coccolithophores are a key phytoplankton group within the Greenland and Norwegian Sea (Samtleben \& Schröder 1992). The highest species diversities are found in the Norwegian Sea (Samtleben \& Schröder 1992, Baumann et al. 2000), as the more diverse North Atlantic communities are transported northwards by the Norwegian Current. The Norwegian Sea coccolithophore community is generally dominated by E. huxleyi (Samtleben \& Schröder 1992, Baumann et al. 2000, Charalampopoulou et al. 2011), with some species, such as Calciopappus caudatus, present throughout, while other species, such as Syracosphaera spp., are limited to Atlantic surface waters. In contrast, coccolithophore diversity is lower in the Greenland Sea (Samtleben \& Schröder 1992); C. pelagicus is commonly observed along with other polar species (e.g. Papposphaera spp.). The contrast in coccolithophore community structure and diversity, coupled with the strong natural environmental gradients of the Greenland and Norwegian Seas, means that this region is an ideal location to examine the influence of both the environment and the coccolithophore community structure on calcite production.

The aim of this study was to determine whether E. huxleyi was the major calcite producer in the Arctic Ocean, and if not, which coccolithophore species were. As only total community calcite production (CP) can be measured from mixed communities (e.g. Charalampopoulou et al. 2011, Poulton et al. 2014), a novel method was developed to determine species-specific calcite production $\left(\mathrm{CP}_{\mathrm{sp}}\right)$ for each individual coccolithophore species. This method incorporates species-specific cellular calcite, growth rates and abundances to partition CP. 
This is the first study to determine the calcite production rates of individual coccolithophore species within a natural multi-species community. Here we present results from 19 stations within the Arctic Ocean and the subarctic Iceland Basin (Fig. 1); calcite production (CP), coccolithophore cellular abundances, carbonate chemistry parameters and other environmental variables were measured, and $\mathrm{CP}_{\mathrm{sp}}$ derived for each station.

\section{Methods}

\section{Sampling}

Sampling was carried out in the subarctic Iceland Basin, and the Greenland and Norwegian Seas within the Arctic Ocean (Fig. 1) between June $4^{\text {th }}$ and $30^{\text {th }} 2012$ during the UK Ocean Acidification Arctic Cruise, aboard the RRS James Clark Ross (JR271). Water samples for rate measurements, coccolithophore community structure and ancillary measurements, were collected from a single depth within the middle of the mixed layer at 19 CTD stations. Temperature and salinity were obtained from the CTD. Incidental photosynthetically active radiation (PAR), measured with ship-mounted scalar irradiance sensors (Kipp \& Zonen ParLite 0348900, Skye Instruments SK3), was integrated over the incubation periods to calculate daily incidental irradiance (mol photons $\mathrm{m}^{-2} \mathrm{~d}^{-1}$ ). The vertical diffuse attenuation coefficient of PAR $\left(\mathrm{K}_{\mathrm{d}}\right)$ in the water column was calculated from the CTD casts, with the depth of the euphotic zone $\left(Z_{\text {eup }}\right)$ calculated as the depth of $1 \%$ incident irradiance.

\section{Calcite production}

Daily rates of calcite production were measured using the micro-diffusion technique (Paasche \& Brubak 1994, Balch et al. 2000) following Poulton et al. (2014). Water samples (70 mL, 3 light, 1 formalin-killed), collected from one depth within the middle of the mixed layer, were inoculated with $25-50 \mu \mathrm{Ci}{ }^{14} \mathrm{C}$ labelled sodium bicarbonate. Samples were incubated for 24 hours in an on-deck incubator, chilled with surface seawater and the 55\% incidental irradiance light depth was replicated using Misty-blue optical filters ( $\mathrm{LEE}^{\mathrm{TM}}$ ). When the surface seawater supply was unavailable (at ice stations), samples were incubated in a constant temperature container laboratory (see Richier et al. 2014) with the temperature and photoperiod set to replicate the in situ environment. Formalin-killed blanks were prepared by addition of $1 \mathrm{~mL}$ of $0.2 \mu \mathrm{m}$ triple-filtered and sodium-borate buffered formalin solution. Incubations were terminated by filtration through $25 \mathrm{~mm} 0.45 \mu \mathrm{m}$ polycarbonate filters $\left(\right.$ Nuclepore $\left.{ }^{\mathrm{TM}}\right)$. Filters were secured in glass scintillation vials with a gas-tight septum and a 
139 bucket containing a $\mathrm{CO}_{2}$ trap (Whatman GFA filter soaked with $200 \mu \mathrm{l} \beta$-phenylethylamine),

140 acidified with a weak acid ( $1 \mathrm{ml}, 1 \%$ phosphoric acid), thus releasing the acid-labile

141 inorganically fixed carbon (CP) as ${ }^{14} \mathrm{CO}_{2}$ to be absorbed by the $\mathrm{CO}_{2}$ trap. After 24 hours, the

142 GFA filters were removed to separate scintillation vials, and the activity of the filters was

143 determined in Ultima Gold (Perkin-Elmer, UK) and their activity measured using a Tri-Carb

1442100 Low Level Liquid Scintillation Counter. Spike activity was checked following Poulton

145 et al. (2014).

146 The average coefficient of variation of the triplicate (light) CP measurements was $27 \%$ (3 -

$147113 \%$ ), and the formalin-killed blank represented on average $26 \%$ (7 - $60 \%$ ) of the CP

148 signal, with generally higher contributions in lower CP signals. These are comparable to

149 other studies using the same method (e.g. Poulton et al. 2010, Poulton et al. 2014).

\section{Coccolithophore community structure}

Water samples $(100-250 \mathrm{~mL})$ for the determination and enumeration of the coccolithophore community were collected following Poulton et al. (2014). Permanent slides were prepared on board using a low viscosity Norland Optical Adhesive (NOA 74) (Poulton et al. 2014). Coccolithophore cell counts and species identification were performed using a Leitz Ortholux polarizing microscope (x1000, oil immersion). A minimum of 54 fields of view were counted per filter for abundant species, with additional fields of view analysed for rarer species. The light microscopy species identification and enumeration were verified and supplemented using scanning electron microscopy (SEM) following Daniels et al. (2012).

\section{Species-specific calcite production}

160 The equation to determine species-specific calcite production $\left(\mathrm{CP}_{\mathrm{sp}}\right)$ was adapted from

161 Daniels et al. (2014). $\mathrm{CP}_{\text {sp }}$ is calculated as a product of the growth rate $(\mu)$, cellular calcite

162 content (C) and abundance (N) of each species present (Eqn. 1). Species-specific calcite

163 content was estimated from SEM images by combining derived estimates of coccolith calcite 164 (Young \& Ziveri 2000) with the number of coccoliths per cell (Table 1). The method of 165 Young and Ziveri (2000) incorporates species-specific coccolith shape factors $\left(\mathrm{k}_{\mathrm{s}}\right)$. Of the species observed here, only 4 (E. huxleyi, C. pelagicus, A. quattrospina, Syracosphaera spp.) had a pre-defined $k_{s}$. For those species with an undefined shape factor, shape factors were estimated from SEM images for C. pelagicus HOL and C. caudatus (Table 1), the $\mathrm{k}_{\mathrm{s}}$ for $A$. robusta was adapted from E. huxleyi (Probert et al. 2007), and a "typical coccolith" $\mathrm{k}_{\mathrm{s}}$ was used for Ophiaster sp. (Young \& Ziveri 2000). 
$171 \quad C P_{s p}=\frac{\mu_{s p} C_{s p} N_{s p}}{\sum_{i=1}^{n} \mu_{i} C_{i} N_{i}} \times C P_{b u l k}$

172 Species-specific growth rates cannot be directly determined from the measurements we made.

173 However we can use relative growth rates to determine the fraction of calcite production per species, and multiply this by the measured total CP to obtain $\mathrm{CP}_{\text {sp }}$ (Eqn. 1). Initially we have made the simplifying assumption that all coccolithophores have the same growth rate as there is little data on relative growth rates of coccolithophores in the field or from laboratory experiments (Daniels et al. 2014, Daniels et al. 2015). The influence of variable growth rates for different species on the estimates of $\mathrm{CP}_{\mathrm{sp}}$ will be examined in the discussion.

\section{Macronutrients and carbonate chemistry}

180 Macronutrients (nitrate + nitrite, $\mathrm{NO}_{\mathrm{x}}$; phosphate, $\mathrm{PO}_{4}$; silicic acid, dSi) were determined 181 following Sanders et al. (2007) on a Skalar autoanalyser. The relative concentration of $\mathrm{NO}_{\mathrm{x}}$ to $182 \mathrm{PO}_{4}\left(\mathrm{~N}^{*} ; \mathrm{NO}_{\mathrm{x}}-16 \times \mathrm{PO}_{4}\right.$ (Moore et al. 2009)) and the relative concentration of dSi to $\mathrm{NO}_{\mathrm{x}}$ 183 (Si*; dSi - $\mathrm{NO}_{\mathrm{x}}$ (Bibby \& Moore 2011)) were also determined.

184 Samples for total dissolved inorganic carbon $\left(C_{\mathrm{T}}\right)$ and total alkalinity $\left(A_{\mathrm{T}}\right)$ were collected into $250 \mathrm{~mL}$ borosilicate glass bottles and poisoned with $50 \mu \mathrm{L}$ of saturated mercuric chloride solution following (Dickson et al. 2007). Using a VINDTA 3C instrument (Marianda,

187 Germany), $C_{\mathrm{T}}$ was measured by coulometric titration, and $A_{\mathrm{T}}$ by potentiometric titration and calculated using a modified Gran technique (Bradshaw et al. 1981). The results were calibrated using certified reference material (batch 117) obtained from A.G. Dickson (Scripps Institution of Oceanography, USA). Measurement precision was \pm 3.8 and $\pm 1.7 \mu \mathrm{mol} \mathrm{kg}{ }^{-1}$ for $C_{\mathrm{T}}$ and $A_{\mathrm{T}}$ respectively. Calcite saturation state $\left(\Omega_{\mathrm{c}}\right), \mathrm{pH}$ on the Total scale $\left(\mathrm{pH}_{\mathrm{T}}\right)$ and seawater partial pressure of $\mathrm{CO}_{2}\left(\mathrm{pCO}_{2}{ }^{\mathrm{sw}}\right)$ were calculated using version 1.1 of the $\mathrm{CO}_{2} \mathrm{SYS}$

193 program for MATLAB (Van Heuven et al. 2011) using the carbonic acid dissociation 194 constants of Lueker et al. (2000), the boric acid dissociation constant of Dickson (1990b), the 195 bisulfate ion acidity constant of Dickson (1990a), and the boron:chlorinity of Lee et al. 196 (2010).

197 Data availability and statistical analysis

198 All data included in the paper are available from the British Oceanographic Data Centre 199 (BODC). Multivariate statistics were used to examine spatial variability in the 
coccolithophore species composition and $\mathrm{CP}_{\mathrm{sp}}$ (biotic data) and the environment (abiotic data). Bray-Curtis similarity resemblance matrices were calculated from the standardised biotic data to determine changes in species composition and $\mathrm{CP}_{\mathrm{sp}}$. The abiotic data (temperature, salinity, $\Omega_{\mathrm{C}}, \mathrm{pH}_{\mathrm{T}}, \mathrm{N}^{*}, \mathrm{Si}^{*}$, daily PAR and $\mathrm{Z}_{\text {eup }}$ ) were normalised, and a Euclidean distance resemblance matrix calculated to determine changes in the environmental variables. The species composition of samples via the Bray-Curtis similarity index was then used to cluster samples into groups using non-metric multi-dimensional scaling (NMDS). The species typical of each hydrographic region were identified using a breakdown of similarity percentages (SIMPER routine), calculated in E-PRIMER (Clarke 1993). Spearman’s rank correlation (BEST routine) were calculated in E-PRIMER (Clarke 1993) to identify which environmental variables explained most of the variation in the coccolithophore community and $\mathrm{CP}_{\mathrm{sp}}$.

Principal component analysis (PCA) of normalised environmental variables was performed using MATLAB, and Pearson product-moment correlations were carried out between the calculated principal components (PC) and coccolithophore community composition and $\mathrm{CP}_{\mathrm{sp}}$ to further examine the relationship between the biotic and abiotic data.

\section{Results}

\section{General Oceanography}

A wide variety of hydrographic environments were sampled during the cruise, throughout the Iceland Basin and the Nordic Seas (Greenland Sea and Norwegian Sea) of the Arctic Ocean (Fig. 1, Table 2), with two major fronts dividing the regions; the Norwegian Sea was separated from the Iceland Basin by the Iceland-Faroes Front, while the East Greenland Front separated the Greenland Sea from the Norwegian Sea (Cottier et al. 2014). The Iceland Basin was characterised by the warmest $\left(10-10.6^{\circ} \mathrm{C}\right)$ and most saline $(35.2-35.3)$ waters of the study. The Greenland Sea, with the influence of the East Greenland Current, had the coldest $\left(1-3.5^{\circ} \mathrm{C}\right)$ and freshest $(34.7-35.0)$ waters sampled. The Norwegian Sea lay between the two extremes of the Iceland Basin and the Greenland Sea, in terms of both temperature (3.1 $\left.7.8^{\circ} \mathrm{C}\right)$ and salinity (34.8 - 35.2).

Macronutrient concentrations of $\mathrm{NO}_{\mathrm{x}}\left(0.5-10.6 \mathrm{mmol} \mathrm{N} \mathrm{m}^{-3}\right), \mathrm{PO}_{4}\left(0.11-0.77 \mathrm{mmol} \mathrm{P} \mathrm{m}^{-3}\right)$ and dSi $\left(1.3-6.1 \mathrm{mmol} \mathrm{Si} \mathrm{m}^{-3}\right)$ were highly variable and no clear spatial patterns were observed (Table 2). The values of $\mathrm{N}^{*}$ were negative at all sites (-3.0 to -0.3$)$ indicating that, 
assuming Redfield stoichiometry (Redfield, 1958), $\mathrm{NO}_{\mathrm{x}}$ was low relative to $\mathrm{PO}_{4}$. The values

232

233

234

235

236

237

238

239

240

241

242

243 of $\mathrm{Si}^{*}$ ranged from -2.9 to 6.5. While generally positive, indicating high residual dSi concentrations, four stations exhibited a negative $\mathrm{Si}^{*}$, indicating depleted dSi relative to $\mathrm{NO}_{\mathrm{x}}$. No clear spatial patterns in $\mathrm{N}^{*}$ or $\mathrm{Si}^{*}$ were identified between sampling sites.

Euphotic zone depth ( $\mathrm{Z}_{\text {eup }}$ ) ranged from 15 to $50 \mathrm{~m}$, and daily incidental PAR varied from 10 to 53 mol photons $\mathrm{m}^{-2} \mathrm{~d}^{-1}$, with both showing variability within and between regions. As the cruise occurred in mid-summer, the stations in the Nordic Seas experienced a 24 hour photoperiod, while the Iceland Basin stations experienced a shorter photoperiod ( 18 hours). The effect of this on daily PAR is not clear, suggesting a stronger influence through varying cloud cover. Values of $\mathrm{pH}_{\mathrm{T}}$ varied from 8.07 to 8.29 and $\Omega_{\mathrm{C}}$ varied from 2.65 to 4.46, with the low $\Omega_{\mathrm{C}}$ particularly in the Greenland Sea.

\section{Coccolithophore community structure}

Total coccolithophore abundance was highly variable, ranging from 5 to 932 cells $\mathrm{mL}^{-1}$. The most commonly observed coccolithophore species were Emiliania huxleyi (0 - 425 cells mL${ }^{1}$ ), Coccolithus pelagicus ( 0 - 33 cells $\mathrm{mL}^{-1}$ ) and the holococcolithophorid (HOL) life stage of Coccolithus pelagicus $\left(0-223\right.$ cells $\left.\mathrm{mL}^{-1}\right)$ (Fig. 2).

Other species present included Acanthoica quattrospina, Algirosphaera robusta, Calciopappus caudatus, Ophiaster sp. and Syracosphaera spp. (Fig. 2). While each species has been considered individually in determining $\mathrm{CP}_{\mathrm{sp}}$ and in the environmental analysis, for the purpose of graphical representation, species other than E. huxleyi, C. pelagicus and $C$. pelagicus HOL were grouped into one category (termed 'others', Fig. S1) as they were minor contributors to regional calcite production. Scanning electron microscopy identified Syracosphaera spp. as including: S. borealis, S. corolla, S. dilata, S. marginaporata and S. molischii. The cellular calcite content of the Syracosphaera genus however are not well constrained (Young \& Ziveri 2000), thus we have not considered these species individually and have used a "small Syracosphaera" coccolith calcite (Young \& Ziveri 2000) estimate for calculating their cellular calcite. The different coccolithophore species had varying spatial distributions (Fig. S1, Table S1). Emiliania huxleyi was most abundant in the Iceland Basin and Norwegian Sea, C. pelagicus HOL was present in the highest latitude stations, while Syracosphaera spp. were restricted to the Iceland Basin.

To account for the large variability in coccolithophore abundances between stations, the stations were grouped into the three distinct regions (Iceland Basin, Greenland Sea and 
263 Norwegian Sea, Fig. 1, Table S2), as defined from the characteristic hydrography of each station. Coccolithophore abundances, aggregated over these regions, and over the entire study area (Fig. 3A) showed that E. huxleyi represented $27 \%$ of the total coccolithophore abundance, with a relatively consistent contribution across all regions (19 - 30 \%, Fig. 3A). In contrast, Coccolithus pelagicus formed only a small component of the coccolithophore community in terms of abundance ( $1-4 \%$, Fig. 3A) in all regions sampled. The Iceland Basin community was dominated by C. caudatus (43\%) and Syracosphaera spp. (24\%), the Norwegian Sea by C. caudatus (43 \%), and the Greenland Sea by C. pelagicus HOL (77 \%, Fig. 3A).

\section{Species-specific calcite production}

The total community calcite production was highly variable throughout the study (from 2 to $202 \mu \mathrm{mol} \mathrm{C} \mathrm{m}{ }^{-3} \mathrm{~d}^{-1}$ ), with rates similar to those measured previously in the North Sea and the

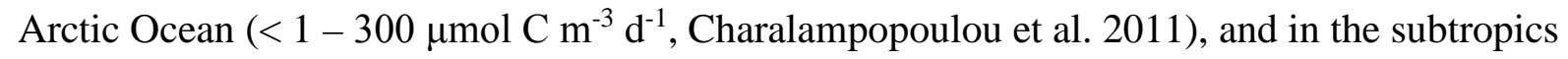
(0.4 - $102 \mu \mathrm{mol} \mathrm{C} \mathrm{m-3} \mathrm{d-1,} \mathrm{Poulton} \mathrm{et} \mathrm{al.} \mathrm{2006),} \mathrm{but} \mathrm{generally} \mathrm{lower} \mathrm{than} \mathrm{those} \mathrm{previously}$ measured on the north-west European shelf $\left(2-825 \mu \mathrm{mol} \mathrm{C} \mathrm{m} \mathrm{m}^{-3} \mathrm{~d}^{-1}\right.$, Poulton et al. 2014).

There were no clear spatial patterns in the distribution of calcite production; the largest

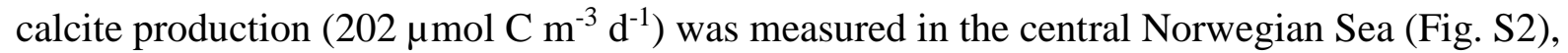
with the lowest rates in the Greenland Sea $\left(<10 \mu \mathrm{mol} \mathrm{C} \mathrm{m} \mathrm{m}^{-3} \mathrm{~d}^{-1}\right)$.

At each individual station, the major calcite producers were E. huxleyi (0 - $100 \%), C$. pelagicus $(0-98 \%)$ and C. pelagicus HOL (0 - $100 \%)$. However, there was significant variability between the stations (Table S3, Fig. S3), and when considering each station individually, E. huxleyi was the largest contributor at 6 stations, C. pelagicus at 10 stations and C. pelagicus HOL at 3 stations. Of the other species present, Syracosphaera spp. were also a significant source in the Iceland Basin $(0-27 \%)$, and C. caudatus was generally a small source $(0-12 \%)$ except at station 20 in the Norwegian Sea where it contributed $37 \%$ of the total calcite production. When present, A. robusta was a minor contributor to calcite production in the Norwegian Sea (3 - $16 \%)$.

Considering the percentage calcite production of each species on a per station basis however does not account for the high variability in the measured total calcite production. Incorporating total calcite production and aggregating over the three regions and the entire cruise reveals that $C$. pelagicus was the major calcifier, responsible for $57 \%$ of the total calcite production (Fig. 3B), with a higher contribution in the Nordic Seas (59-61\%) than 
in the Iceland Basin (44\%). In contrast, E. huxleyi represented only $20 \%$ of the total calcite production (Fig. 3B), with a much smaller contribution in the Greenland Sea (6\%) than in the Norwegian Sea (26 \%) and Iceland Basin (25\%). Coccolithus pelagicus HOL was a significant calcite producer in the Greenland Sea (28\%), but less so in the other regions, resulting in a total contribution of only $12 \%$ (Fig. 3B). The contribution of the other species to calcite production was greatest in the Iceland Basin (29 \%), of which Syracosphaera spp. (19\%) and C. caudatus (7 \%) were the major calcifiers. In the Arctic, C. caudatus (2 - $5 \%$ ) and $A$. robusta $(0-7 \%)$ were the largest calcite producers of the other coccolithophore species present.

\section{Coccolithophore species composition, $\mathrm{CP}_{\mathrm{sp}}$ and environmental variables}

305

306

307

308

309

310

311

312

313

314

315

316

317

318

319

320

321

322

323

In order to explore the relationship between the environmental variables and the species composition of the coccolithophore community and their contribution to $\mathrm{CP}_{\mathrm{sp}}$, a PCA was carried out using normalised environmental variables (temperature, salinity, $\Omega_{\mathrm{C}}, \mathrm{pH}, \mathrm{N}^{*}, \mathrm{Si}^{*}$, daily PAR and $\mathrm{Z}_{\text {eup }}$ ). The first principal component (PC-1) explained $40.1 \%$ of the variance between stations in terms of the environmental conditions, while the second principal component (PC-2) explained a further $33.3 \%$ of the variance. Therefore, the combination of PC-1 and PC-2 explained $73.4 \%$ of the total environmental variability.

Eigenvalues from the PCA (Table 5) indicate the relative weight of the environmental variables in influencing each of the PCs. Pearson moment correlations showed that PC-1 was strongly related to $\Omega_{\mathrm{C}}, \mathrm{pH}$ and $\mathrm{Si}^{*}$ and $\mathrm{Z}_{\text {eup }}$ while PC-2 was related to temperature, salinity and $\mathrm{N}^{*}$ (Table 5). Correlated with latitude ( $r=0.68, p<0.005, n=19$ ), PC-2 essentially describes the north-south environmental gradient, with warmer, more saline and high $\mathrm{N}^{*}$ waters in the south. Correlations between PCs, coccolithophore composition and $\mathrm{CP}_{\mathrm{sp}}$ found significant correlations $(p<0.005)$ between PC-1 and the contribution of E. huxleyi and $C$. pelagicus HOL to species composition, and between PC-1 and the percentage contribution to $\mathrm{CP}_{\mathrm{sp}}$ by $E$. huxleyi $(p<0.005)$ and $C$. pelagicus HOL $(p<0.05)$. PC-2 was significantly correlated $(p<0.005)$ with the composition and percentage contribution to $\mathrm{CP}_{\mathrm{sp}}$ of Syracosphaera spp., A. quattrospina and Ophiaster sp. These species were found only in the Iceland Basin samples, further demonstrating the link between PC-2 and the north-south environmental gradient.

To visualise the multivariate patterns in similarity between the individual stations in terms of community composition, non-metric multi-dimensional scaling (NMDS) analysis was applied 
to both species composition data (Fig. 6A) and $\mathrm{CP}_{\mathrm{sp}}$ (Fig. 6B). The stress values of the 2-

328

329

330

331

332

333

334

335

336

337

338

339

340

341

342

343

344

345

346

347

348

349

350

351

352

353

354

355

356 dimensional NMDS plots were low $(<0.08)$, thus indicating that they are a good representation of the high-dimensional patterns (Clarke 1993). The NMDS plots reveal different patterns of similarity between the stations whether species composition or $\mathrm{CP}_{\mathrm{sp}}$ are considered. To examine the underlying factors driving the similarity between stations, individual species contributions to community composition (Fig. 6B-D) and $\mathrm{CP}_{\mathrm{sp}}$ (Fig. 6F-H) where overlaid on to the NMDS plots. In terms of species composition, the spatial pattern was generally explained by the contributions of E. huxleyi (Fig. 6B) and C. pelagicus HOL (Fig. 6D) to community composition. The majority of Greenland Sea samples clustered distinctly away from other stations (Fig. 6A), with their coccolithophore communities comprised of a large contribution from $C$. pelagicus HOL and a small contribution from $E$. huxleyi.

The dissimilarities in species contribution to community composition between stations in the different hydrographic regions were tested statistically using a SIMPER analysis. The high dissimilarity between stations in the Greenland Sea and those in both the Iceland Basin (average dissimilarity $=85.6 \%$ ) and the Norwegian Sea (average dissimilarity $=82.3 \%$ ) was driven by C. pelagicus HOL ( $43-44 \%$ of dissimilarity) and E. huxleyi (26 - $27 \%$ of dissimilarity), as observed in the NMDS plots. The spatial patterns in the $\mathrm{CP}_{\mathrm{sp}}$ NMDS plots contrasted that of species composition (Fig. 6E), being influenced by E. huxleyi (Fig. 6F), C. pelagicus (Fig. 6G) and C. pelagicus HOL (Fig. 6H). The Greenland Sea stations did not cluster separately in this case, as they did for analysis of their coccolithophore community composition; SIMPER analysis found that that the hydrographic regions were more similar in terms of $\mathrm{CP}_{\mathrm{sp}}$ (average dissimilarity $<71 \%$ ) than in terms of species composition.

To determine which environmental variables best explain the patterns in species composition and $\mathrm{CP}_{\mathrm{sp}}$, Spearman's rank correlations $\left(r_{\mathrm{s}}\right)$ were calculated between resemblance matrices of abiotic and biotic data (Clarke 1993). The variability in species composition between stations was best explained by temperature, $\Omega_{\mathrm{C}}$, and $\mathrm{N}^{*}\left(r_{s}=0.55, p<0.01\right.$, Table 6$)$, while the single variable that explained most of the variability was $\Omega_{\mathrm{C}}\left(r_{s}=0.55, p<0.01\right)$. The variability in $\mathrm{CP}_{\mathrm{sp}}$ was best correlated with $\Omega_{\mathrm{C}}$ (Table 6) though the relationship was slightly weaker $\left(r_{\mathrm{s}}=\right.$ $0.37 p<0.01)$ than for species composition.

\section{Discussion}


359 Calculating $\mathrm{CP}_{\mathrm{sp}}$ reveals that C. pelagicus is the major calcifier in this Arctic study, 360 responsible for $57 \%$ of the calcite production in the Arctic Ocean and sub-polar Iceland

361 Basin, despite forming only $2 \%$ of the total coccolithophore community abundance (Fig. 3).

362 The influence of $C$. pelagicus on calcite production is further confirmed by a significant 363 correlation between C. pelagicus abundance and total calcite production $(r=0.55, p<0.02, n$ $364=19$ ); no other species correlated significantly with total calcite production. That $C$.

365 pelagicus is able to dominate calcite production at such low relative abundances is due to its 366 significantly higher cellular calcite quota compared to the rest of the coccolithophore species

367

368

369

370

371

372

373

374

375

376

377

378

379

380

381

382

383

384

385

386

387

388

389

390

391 present in the community (Table 1). This potential to dominate community calcite production has been previously identified in a simplified two species model of C. pelagicus and $E$. huxleyi (Daniels et al. 2014). Although the natural communities in our samples are more complex and species-rich, C. pelagicus still has at least a 20 fold greater cellular calcite quota than the rest of the community (Table 1 ). Thus, when present $C$. pelagicus usually dominates coccolithophore calcite production.

The dominance of $C$. pelagicus in our study is not dependent on any single station. Removing the station (CTD 58) which has the highest rate of calcite production $\left(202 \mu \mathrm{mol} \mathrm{C} \mathrm{m}^{-3} \mathrm{~d}^{-1}\right)$, and therefore the largest influence over $\mathrm{CP}_{\mathrm{sp}}$, does not change the overall result. Although removing this station from the analysis results in a reduction of $C$. pelagicus-derived calcite production from $57 \%$ to $43 \%$, C. pelagicus remained the single species with the largest source of calcite in the mixed communities of the Arctic Ocean and Iceland Basin. The effect of removing any other station from the analysis was minimal with $C$. pelagicus remaining the dominant calcifier.

Although E. huxleyi is often perceived to be the most abundant and the keystone coccolithophore species (Paasche 2002), we found that it was neither the most abundant (27 $\%$ total abundance, Fig. 3A), or the major calcifier (20\% of total calcite production, Fig. 3B), suggesting that it may not be the keystone species of coccolithophore in the North Atlantic and Arctic. However, previous studies have identified E. huxleyi as the most abundant coccolithophore in the Norwegian Sea $\left(0-3000\right.$ cells $\left.\mathrm{mL}^{-1}\right)$, although $C$. pelagicus was still an important component $\left(0-30\right.$ cells $\left.\mathrm{mL}^{-1}\right)$ of the communities studied (Baumann et al. 2000, Charalampopoulou et al. 2011). This change in dominance between studies is possibly due to seasonal (Baumann et al. 2000) or interannual variability occurring within the coccolithophore community. However, an increase in the abundance of E. huxleyi, coupled with a reduction in the abundance of other species such as $C$. caudatus and A. robusta, would 

$\%$ ) despite forming only a small fraction (2\%) of the coccolithophore community. Despite dominating calcite production in this study, C. pelagicus is unlikely to be a globally dominant calcite producer, as its global distribution is constrained to the Arctic Ocean and sub-polar regions of the North Atlantic and North Pacific (McIntyre \& Bé 1967, Ziveri et al. 2007). While other heavily calcified species (e.g. Calcidiscus leptoporus, Helicosphaera carteri) are more widely distributed (Ziveri et al. 2007) and thus have the potential to dominate calcite production (Daniels et al. 2014), here we show the biogeochemical importance of holococcolith bearing coccolithophores (i.e. C. pelagicus HOL) and relatively weakly calcified but highly abundant coccolithophore species (i.e. C. caudatus). Further research into these lesser-studied species is required in order to improve our understanding of the role of different species in calcite production.

\section{A robust measure of species-specific calcite production?}

405

406

407

408

409

410

411

412

413

414

415

416

417

418

419

420

421

422

423

As $\mathrm{CP}_{\mathrm{sp}}$ cannot be directly determined, its calculation requires assumptions with associated potential errors. The two main sources of error are the estimates of both cellular calcite and growth rates. With the natural variability in coccolith size and shape, the error in determining cellular calcite is estimated to be 30 to 50 \% (Young \& Ziveri 2000, Daniels et al. 2012). We have minimised this error by using species-specific shape factors together with measurements of coccolith length in SEM images, and our estimates of cellular calcite for $C$. pelagicus (15.2 pmol C cell-1 $)$ and E. huxleyi $\left(0.52 \mathrm{pmol} \mathrm{C} \mathrm{cell}^{-1}\right)$ are comparable to literature values (16.6 pmol C cell ${ }^{-1}$ and $0.22-1.1$ pmol C cell $^{-1}$ respectively, (see Paasche 2002, Daniels et al. 2014)). Although E. huxleyi is perceived to be a fast growing coccolithophore species relative to other species (Paasche 2002, Tyrrell \& Merico 2004), little data exists concerning relative in situ growth rates of coccolithophores in mixed communities. Furthermore, recent culture experiments (Daniels et al. 2014) and time series field data (Daniels et al. 2015) suggest that E. huxleyi may not be a relatively faster growing species in situ, with net growth rates of $C$. pelagicus similar to or higher than $E$. huxleyi in early spring North Atlantic communities.

To test the influence of these assumptions on species-specific calcite production, the growth rates of the three main calcifiers, E. huxleyi (Fig. 7A), C. pelagicus (Fig. 7B), and C. pelagicus HOL (Fig. 7C) were independently varied relative to the community growth rate, such that they had a growth rate between 10 and $200 \%$ relative to the community. This is a 
424 similar approach to that used in Daniels et al. (2014) where growth rates and cellular calcite 425 contents of $C$. pelagicus were varied to demonstrate that $C$. pelagicus was of potential 426 biogeochemical importance when growing significantly slower and/or at lower relative 427 abundances. In the resulting scenarios of our Arctic analysis, C. pelagicus remains the major 428 calcifier except when its relative growth rate was less than $15 \%$ of the rest of the community 429 (Fig. 7B). In a further perturbation of the community, the relative growth rate of E. huxleyi 430 was increased to $200 \%$ before varying the relative growth rate of $C$. pelagicus. In this 431 scenario, C. pelagicus did not dominate calcite production with a growth rate less than $30 \%$ 432 of the total community growth rate. Even in this extreme and potentially unrealistic scenario, 433 C. pelagicus remained a significant single species calcifier (> $20 \%$ ). Although these 434 scenarios demonstrate the potential influence of variable growth rates on $\mathrm{CP}_{\mathrm{sp}}$, and that

435 further research is required to constrain both cellular calcite quotas and coccolithophore 436 growth rates, C. pelagicus remained the dominant calcifier in the Arctic Ocean in all but the 437 most extreme scenarios.

438 How does Coccolithus pelagicus dominate Arctic community CP?

439 It is well established that $C$. pelagicus is commonly found in the Arctic Ocean, but forms 440 only a small component of the overall coccolithophore community (Samtleben \& Schröder 441 1992, Baumann et al. 2000, Charalampopoulou et al. 2011), as observed here. Yet, the 442 importance of $C$. pelagicus as a calcite producer has not previously been recognised. That $C$. 443 pelagicus is a disproportionately larger contributor to calcite production than abundance is 444 due to the significantly higher cellular calcite content of C. pelagicus than other 445 coccolithophore species. However, how is it able to dominate calcite production - is it due to 446 the absence of E. huxleyi or is it due to C. pelagicus being present in relatively high enough 447 cellular abundances? Furthermore, what environmental characteristics determine these two 448 factors?

449 To examine these competing factors we can compare and contrast the compositional analysis 450 based on species composition in terms of cell abundances and in terms of species-specific 451 calcite production. The NMDS plots of species composition show that the relative abundance 452 of E. huxleyi in the community is a major driver of the variability in species composition 453 between stations (Fig. 6B), whereas C. pelagicus has little influence (Fig. 6C). This is due to 454 C. pelagicus being present in all most all samples but forming only a small fraction of the 455 community. In contrast, E. huxleyi numerically dominates at some stations, but is totally 
absent from others (Table 3). This would suggest that as $C$. pelagicus dominates calcite production at stations where $E$. huxleyi is present and absent, it is the relative abundance of $C$. pelagicus that allows it to dominate calcite production.

The pattern in the NMDS plots of $\mathrm{CP}_{\mathrm{sp}}$ however, with E. huxleyi (Fig. 6F) and C. pelagicus (Fig. 6G) both strongly influencing variability in $\mathrm{CP}_{\mathrm{sp}}$, suggest that $C$. pelagicus is responsible for a greater proportion of calcite production when the contribution of E. huxleyi is low. The difference between species composition and species contribution to calcite production between stations suggest that the dominance of $C$. pelagicus in terms of calcification is a combination of both the relative abundance of $C$. pelagicus compared to all other species of coccolithophore, and the relative absence of E. huxleyi, particularly from stations within the Greenland Sea (Fig. 6). Therefore species composition has a significant impact on calcite production and which species dominate calcification in the Arctic Ocean. In terms of understanding variability in calcite production in the Arctic Ocean, it is then important to determine what drives the variability in species composition throughout the Arctic. Variability in the physicochemical environment is clearly recognised as influencing the biogeography of coccolithophores (e.g. Charalampopoulou et al. 2011, Poulton et al. 2013). However, the relationship between species composition and environmental variables is complex and difficult to directly elucidate. Other studies have linked variability in coccolithophore community composition and calcite production to carbonate chemistry (Charalampopoulou et al. 2011, Smith et al. 2012), irradiance (Poulton et al. 2010, Charalampopoulou et al. 2011, Poulton et al. 2014), and nutrient availability (Poulton et al. 2011, Poulton et al. 2014).

Using the same multivariate statistical approach as used by Charalampopoulou et al. (2011) on the data collected in this study, Spearman's rank correlations identified temperature, $\Omega_{\mathrm{C}}$, and $\mathrm{N}^{*}$ as the environmental variables that could best explain species composition (Table 6). This contrasts with the results from Charalampopoulou et al. (2011) who found that $\mathrm{pH}$ and irradiance were the main drivers of coccolithophore species abundance along a transect from the North Sea to the Arctic Ocean. The influence of temperature and $\mathrm{N}^{*}$ on species composition is likely to be due to the contrasting community composition in the warmer (> $10{ }^{\circ} \mathrm{C}$ ) and less nitrate depleted ( $\mathrm{N}^{*}$ of -0.4 to -1.3$)$ Iceland Basin compared to the colder $(<8$ ${ }^{\circ} \mathrm{C}$ ) and more nitrate depleted ( $\mathrm{N}^{*}$ of -1.2 to -3.0 ) Norwegian and Greenland Seas. That PC-2, which was related to temperature $(r=0.87, p<0.005, n=19)$ and $\mathrm{N}^{*}(r=0.83, p<0.005, n$ $=19$ ), and correlated with latitude ( $r=0.68, p<0.005, n=19$ ), correlated with those species 
found only in the Iceland Basin (Syracosphaera spp., A. quattrospina and Ophiaster sp.), further confirms the role of temperature in influencing species composition. However, temperature did not significantly affect $\mathrm{CP}_{\mathrm{sp}}$, with $\Omega_{\mathrm{C}}$ alone best explaining the contribution of species to $\mathrm{CP}_{\text {sp. }}$. Those species limited only to the Iceland Basin, thus strongly influenced by temperature, were relatively minor contributors to calcite production $(0-27 \%)$ and had little impact on the variability in $\mathrm{CP}_{\mathrm{sp}}$.

That both species composition and $\mathrm{CP}_{\mathrm{sp}}$ were affected by $\Omega_{\mathrm{C}}$ can be further examined using the results from the PCA: PC-1, which is positively correlated to $\Omega_{\mathrm{C}}(r=0.92, p<0.005, n$ $=19$ ), is also positively correlated to the contribution of E. huxleyi to both species composition ( $r=0.85, p<0.005, n=19)$ and $\mathrm{CP}_{\mathrm{sp}}(r=0.67, p<0.005, n=19)$, but is negatively correlated to the contribution of $C$. pelagicus HOL to both species composition ( $r$ $=-0.60, p<0.01, n=19)$ and $\mathrm{CP}_{\mathrm{sp}}(r=-0.57, p<0.05, n=19)$. This suggests that $E$. huxleyi represents a smaller fraction of the coccolithophore community in regions of lower saturation state, whereas $C$. pelagicus HOL represents a higher fraction in these conditions. This could be interpreted to suggest that the expected decline in saturation state in the future would reduce the abundance of $E$. huxleyi. However, our analysis does not allow us to conclude that $\Omega_{\mathrm{C}}$ is directly affecting species composition, but rather that within the present day Arctic Ocean, E. huxleyi forms a smaller component of the coccolithophore community in regions of lower $\Omega_{\mathrm{C}}$. It should be noted that $\Omega_{\mathrm{C}}$ was above the saturation point at all stations and that the gradient in saturation state was much lower $(2.6$ - 4.2) than other environmental variables, such as the gradient in temperature $\left(1.0-10.6^{\circ} \mathrm{C}\right)$ and $\mathrm{NO}_{\mathrm{x}}\left(0.5-10.6 \mathrm{mmol} \mathrm{N} \mathrm{m}{ }^{-3}\right)$. Temperature is recognised to have a significant control on coccolithophore distributions, for example, there is a well recognised $2{ }^{\circ} \mathrm{C}$ limit to the range of E. huxleyi (Holligan et al. 2010), while C. pelagicus is able to persist in sub-zero temperatures (Braarud 1979).

513 The relationship between the environment, the coccolithophore community and calcite

514 production is likely to be more complex than presented here; we found no significant environmental influence on total calcite production ( $p=0.09$ ), or the contribution of $C$. pelagicus to species-specific calcite production $(p=0.1)$, implying that other ecophysiological and environmental interactions exist and may influence species biogeography. Furthermore, correlations of individual environmental variables with abundance and $\mathrm{CP}_{\mathrm{sp}}$ did not produce any significant results, further demonstrating the complexity of the interaction between coccolithophore abundance, calcite production, and environmental variables (Poulton et al. 2014). While the influence of some environmental 
522

523

524

525

526

527

528

529

530

531

532

533

534

535

536

537

538

539

540

541

542

543

544

545

546

547

548

549

550

551

552

553

variables (e.g. temperature) on coccolithophore physiology are well established, we are only beginning to get a mechanistic understanding of the influence of carbonate chemistry; for example, calcite production appears dependent on bicarbonate as its primary substrate, and is inhibited by protons (Bach et al. 2015), with $\Omega_{\mathrm{C}}$ not directly affecting calcite formation (Bach 2015). However, we still have very little basic understanding of coccolithophore physiology; for example, until we understand why coccolithophores calcify, and the energetic costs associated with it, we cannot fully understand how cellular calcification will respond to a changing ocean, and the impact this will have on the coccolithophore community in terms of species composition or competitive fitness.

\section{Wider Implications}

Research into the effect of ocean acidification and climate change on coccolithophores has been dominated by studies of E. huxleyi as it is globally abundant and forms large-scale blooms of significant biogeochemical importance (Holligan et al. 1993, Poulton et al. 2013). However, E. huxleyi can be considered an atypical coccolithophore species in terms of its genetic lineage, physiology and ecology (de Vargas et al. 2007), and therefore the response of E. huxleyi to climate change and ocean acidification may not apply to other coccolithophore species. Few studies have examined the impact of ocean acidification on other species of coccolithophore (Langer et al. 2006, Fiorini et al. 2011, Krug et al. 2011), and very little is known about the Arctic species $C$. pelagicus. As a key calcifier in a region considered particularly vulnerable to ocean acidification and warming, the response of $C$. pelagicus to climate change and ocean acidification could have a major effect on calcite production in the Arctic and sub-polar Iceland Basin. Examination of the fossil record of C. pelagicus during the Palaeocene-Eocene Thermal Maximum (PETM), arguably the best geological equivalent of modern-day climate change, found that it was not able to maintain optimum growth during this period (Gibbs et al. 2013), and had reduced calcification rates (O’Dea et al. 2014). If C. pelagicus exhibits a similar response in the modern ocean to current perturbations, it could cause a significant reduction in calcite production within the Arctic Ocean and Iceland Basin, with a major impact on carbon cycling in the North Atlantic.

\section{Acknowledgements}

We acknowledge the UK Natural Environmental Research Council (NERC; Grant references NE/H017097/1 and NE/H017348/1), Department of Environment, Food and Rural Affairs (Defra), and Department of Energy and Climate Change (DECC) for funding the research 
cruise via the UK Ocean Acidification research programme, and to the Danish, Icelandic and Norwegian diplomatic authorities for granting permission to travel and work in Greenland, Iceland and Svalbard coastal and offshore waters. We thank the officers and crew of the RRS James Clark Ross; Mark Stinchcombe for assistance with nutrient measurements, Fred Le Moigne for assistance with sea ice data. MODIS SST data were obtained from the NASA Ocean Color distributed Archive (http://ocenacolor.gsfc.gov/). Sea ice concentration data from the Nimbus-7 SMMR and DMSP SSM/I-SSMIS passive microwave sensors were obtained from the National Snow and Ice Data Center (www.nsidc.org).

\section{References}

ACIA (2004) Arctic Climate Impact and Assessment. Cambridge, UK

Bach LT (2015) Reconsidering the role of carbonate ion concentration in calcification by marine organisms. Biogeosciences 12:4939-4951

Bach LT, Riebesell U, Gutowska MA, Federwisch L, Schulz KG (2015) A unifying concept of coccolithophore sensitivity to changing carbonate chemistry embedded in an ecological framework. Prog Oceanogr 135:125-138

Balch WM, Drapeau DT, Fritz JJ (2000) Monsoonal forcing of calcification in the Arabian Sea. Deep-Sea Res Pt II 47:1301-1337

Baumann KH, Böckel B, Frenz M (2004) Coccolith contribution to South Atlantic carbonate sedimentation. In: Thierstein HR, Young JR (eds) Coccolithophores: from molecular processes to global impact. Springer, Berlin

Baumann K, Andruleit H, Samtleben C (2000) Coccolithophores in the Nordic Seas: Comparison of living communities with surface sediment assemblages. Deep-Sea Res Pt II 47:1743-1772

Bibby TS, Moore CM (2011) Silicate:nitrate ratios of upwelled waters control the phytoplankton community sustained by mesoscale eddies in sub-tropical North Atlantic and Pacific. Biogeosciences 8:657-666

Braarud T (1979) The temperature range of the non-motile stage of Coccolithus pelagicus in the North Atlantic region. British Phycological Journal 14:349-352

Bradshaw AL, Brewer PG, Shafer DK, Williams RT (1981) Measurements of total carbon dioxide and alkalinity by potentiometric titration in the GEOSECS program. Earth and Planetary Science Letters 55:99-115

Broecker W, Clark E (2009) Ratio of coccolith $\mathrm{CaCO}_{3}$ to foraminifera $\mathrm{CaCO}_{3}$ in late holocene deep sea sediments. Paleoceanography 24:PA3205

Charalampopoulou A, Poulton AJ, Tyrrell T, Lucas MI (2011) Irradiance and pH affect coccolithophore community composition on a transect between the North Sea and the Arctic Ocean. Mar Ecol-Prog Ser 431:25-43

Clarke KR (1993) Non-parametric multivariate analyses of changes in community structure. Australian Journal of Ecology 18:117-143 
600

601

602

603

604

605

606

607

608

609

610

611

612

613

614

615

616

617

618

619

620

621

622

623

624

625

626

627

628

629

630

631

632

633

634

635

Cottier F, Hwang P, Drysdale L (2014) JR271 physical oceanography analysis for ocean acidification cruise. SAMS Internal Report 290:31

Daniels CJ, Poulton AJ, Esposito M, Paulsen ML, Bellerby R, St. John M, Martin AP (2015) Phytoplankton dynamics in contrasting early stage North Atlantic spring blooms: composition, succession, and potential drivers. Biogeosciences 12:2395-2409

Daniels CJ, Sheward RM, Poulton AJ (2014) Biogeochemical implications of comparative growth rates of Emiliania huxleyi and Coccolithus species. Biogeosciences 11:69156925

Daniels CJ, Tyrrell T, Poulton AJ, Pettit L (2012) The influence of lithogenic material on particulate inorganic carbon measurements of coccolithophores in the Bay of Biscay. Limnol Oceanogr 57:145-153

de Vargas C, Aubry M, Probert I, Young JR (2007) Origin and evolution of coccolithophores: From coastal hunters to oceanic farmers. In: Falkowski PG, Knoll AH (eds) Evolution of Primary Producers in the Sea. Academic Press, Burlington

Dickson AG (1990a) Standard potential of the reaction: $\mathrm{AgCl}(\mathrm{s})+1 / 2 \mathrm{H}_{2}(\mathrm{~g})=\mathrm{Ag}(\mathrm{s})+$ $\mathrm{HCl}(\mathrm{aq})$, and the standard acidity constant of the ion $\mathrm{HSO}_{4}{ }^{-}$in synthetic seawater from 273.15 to 318.15 K. J Chem Thermodyn 22:113-127

Dickson AG (1990b) Thermodynamics of the dissociation of boric acid in synthetic sea water from 273.15 to 318.15 K. Deep-Sea Res 37:755-766

Dickson AG, Sabine CL, Christian JR (2007) Guide to best practices for ocean $\mathrm{CO}_{2}$ measurements. PICES Special Publication 3

Fiorini S, Middelburg JJ, Gattuso JP (2011) Effects of elevated $\mathrm{CO}_{2}$ partial pressure and temperature on the coccolithophore Syracosphaera pulchra. Aquat Microb Ecol 64:221-232

Gibbs SJ, Poulton AJ, Bown PR, Daniels CJ, Hopkins J, Young JR, Jones HL, Thiemann GJ, O’Dea SA, Newsam C (2013) Species-specific growth response of coccolithophores to Palaeocene-Eocene environmental change. Nat Geosci 6:218-222

Holligan P, Charalampopoulou A, Hutson R (2010) Seasonal distributions of the coccolithophore, Emiliania huxleyi, and of particulate inorganic carbon in surface waters of the Scotia Sea. J Marine Syst 82:195-205

Holligan PM, Fernandez E, Aiken J, Balch WM, Boyd P, Burkill PH, Finch M, Groom SB, Malin G, Muller K, Purdie DA, Robinson C, Trees CC, Turner SM, Vanderwal P (1993) A biogeochemical study of the coccolithophore, Emiliania huxleyi, in the North Atlantic. Global Biogeochem Cy 7:879-900

Hoppe C, Langer G, Rost B (2011) Emiliania huxleyi shows identical responses to elevated $\mathrm{pCO}_{2}$ in TA and DIC manipulations. J Exp Mar Biol Ecol 406:54-62

Iglesias-Rodriguez MD, Halloran PR, Rickaby REM, Hall IR, Colmenero-Hidalgo E, Gittins JR, Green DRH, Tyrrell T, Gibbs SJ, Von Dassow P (2008) Phytoplankton calcification in a high- $\mathrm{CO}_{2}$ world. Science 320:336

Johannessen OM (1986) Brief overview of the physical oceanography. In: Hurdle BG (ed) The Nordic Seas. Springer, Berlin

Krug S, Schulz K, Riebesell U (2011) Effects of changes in carbonate chemistry speciation on Coccolithus braarudii: A discussion of coccolithophorid sensitivities. Biogeosciences 8:771-777 
Langer G, Geisen M, Baumann K, Kläs J, Riebesell U, Thoms S, Young J (2006) Speciesspecific responses of calcifying algae to changing seawater carbonate chemistry. Geochem Geophys Geosyst 7:Q09006

Langer G, Nehrke G, Probert I, Ly J, Ziveri P (2009) Strain-specific responses of Emiliania huxleyi to changing seawater carbonate chemistry. Biogeosciences 6:2637-2646

Lee K, Kim T-W, Byrne RH, Millero FJ, Feely RA, Liu Y-M (2010) The universal ratio of boron to chlorinity for the North Pacific and North Atlantic oceans. Geochimica et Cosmochimica Acta 74:1801-1811

Lohbeck KT, Riebesell U, Reusch TB (2012) Adaptive evolution of a key phytoplankton species to ocean acidification. Nat Geosci 5:346-351

Lueker TJ, Dickson AG, Keeling CD (2000) Ocean pCO2 calculated from dissolved inorganic carbon, alkalinity, and equations for $\mathrm{K}_{1}$ and $\mathrm{K}_{2}$ : validation based on laboratory measurements of $\mathrm{CO}_{2}$ in gas and seawater at equilibrium. Mar Chem 70:1801-1811

McIntyre A, Bé AWH (1967) Modern coccolithophoridae of the Atlantic Ocean-I. Placoliths and cyrtoliths. Deep-Sea Res 14:561-597

Moore CM, Mills MM, Achterberg EP, Geider RJ, LaRoche J, Lucas MI, McDonagh EL, Pan X, Poulton AJ, Rijkenberg MJ (2009) Large-scale distribution of Atlantic nitrogen fixation controlled by iron availability. Nat Geosci 2:867-871

O’Dea SA, Gibbs SJ, Bown PR, Young JR, Poulton AJ, Newsam C, Wilson PA (2014) Coccolithophore calcification response to past ocean acidification and climate change. Nature Communications 5

Paasche E (2002) A review of the coccolithophorid Emiliania huxleyi (Prymnesiophyceae), with particular reference to growth, coccolith formation, and calcificationphotosynthesis interactions. Phycologia 40:503-529

Paasche E, Brubak S (1994) Enhanced calcification in the coccolithophorid Emiliania huxleyi (Haptophyceae) under phosphorus limitation. Phycologia 33:324-330

Poulton AJ, Adey TR, Balch WM, Holligan PM (2007) Relating coccolithophore calcification rates to phytoplankton community dynamics: Regional differences and implications for carbon export. Deep-Sea Res Pt II 54:538-557

Poulton AJ, Charalampopoulou A, Young JR, Tarran GA, Lucas MI, Quartly GD (2010) Coccolithophore dynamics in non-bloom conditions during late summer in the central Iceland Basin (July-August 2007). Limnol Oceanogr 55:1601-1613

Poulton AJ, Painter SC, Young JR, Bates NR, Bowler B, Drapeau D, Lyczsckowski E, Balch WM (2013) The 2008 Emiliania huxleyi bloom along the patagonian shelf: Ecology, biogeochemistry, and cellular calcification. Global Biogeochem Cy 27:2013GB004641

Poulton AJ, Sanders R, Holligan PM, Stinchcombe MC, Adey TR, Brown L, Chamberlain K (2006) Phytoplankton mineralization in the tropical and subtropical Atlantic Ocean. Global Biogeochem Cy 20:GB4002

Poulton AJ, Stinchcombe MC, Achterberg EP, Bakker DCE, Dumousseaud C, Lawson HE, Lee GA, Richier S, Suggett DJ, Young JR (2014) Coccolithophores on the north-west European shelf: calcification rates and environmental controls. Biogeosciences 11:3919-3940 
680

681

682

683

684

685

686

687

688

689

690

691

692

693

694

695

696

697

698

699

700

701

702

703

704

705

706

707

708

709

710

711

712

713

714

715

716

717

718

719

720

721

722

Poulton AJ, Young JR, Bates NR, Balch WM (2011) Biometry of detached Emiliania huxleyi coccoliths along the patagonian shelf. Mar Ecol-Prog Ser 443:1-17

Probert I, Fresnel J, Billard C, Geisen M, Young JR (2007) Light and electron microscope observations of Algirosphaera robusta (Prymnesiophyceae). J Phycol 43:319-332

Richier S, Achterberg EP, Dumousseaud C, Poulton AJ, Suggett DJ, Tyrrell T, Zubkov MV, Moore CM (2014) Phytoplankton responses and associated carbon cycling during shipboard carbonate chemistry manipulation experiments conducted around Northwest European shelf seas. Biogeosciences 11:4733-4752

Samtleben C, Schröder A (1992) Living coccolithophore communities in the NorwegianGreenland Sea and their record in sediments. Mar Micropaleontol 19:333-354

Sanders R, Morris PJ, Stinchcombe M, Seeyave S, Venables H, Lucas M (2007) New production and the $f$ ratio around the Crozet Plateau in austral summer 2004-2005 diagnosed from seasonal changes in inorganic nutrient levels. Deep-Sea Res Pt II 54:2191-2207

Schluter L, Lohbeck KT, Gutowska MA, Groger JP, Riebesell U, Reusch TBH (2014) Adaptation of a globally important coccolithophore to ocean warming and acidification. Nat Clim Change 4:1024-1030

Smith HEK, Tyrrell T, Charalampopoulou A, Dumousseaud C, Legge OJ, Birchenough S, Pettit LR, Garley R, Hartman SE, Hartman MC, Sagoo N, Daniels CJ, Achterberg EP, Hydes DJ (2012) Predominance of heavily calcified coccolithophores at low $\mathrm{CaCO}_{3}$ saturation during winter in the Bay of Biscay. P Natl Acad Sci USA 109:8845-8849

The Royal Society (2005) Ocean acidification due to increasing atmospheric carbon dioxide. Policy Document 12/5. London, UK

Tyrrell T, Merico A (2004) Emiliania huxleyi: bloom observations and the conditions that induce them. In: Thierstein HR, Young JR (eds) Coccolithophores: from molecular processes to global impact. Springer, Berlin

Van Heuven S, Pierrot D, Rae JWB, Lewis E, Wallace DWR (2011) CO2SYS v 1.1, MATLAB program developed for $\mathrm{CO}_{2}$ system calculations. ORNL/CDIAC-105b. In: Carbon Dioxide Information Analysis Center ORNL, U.S DoE, Oak Ridge, TN (ed)

Winter A, Henderiks J, Beaufort L, Rickaby REM, Brown CW (2013) Poleward expansion of the coccolithophore Emiliania huxleyi. J Plankton Res 36:316-325

Young JR, Geisen M, Cros L, Kleijne A, Sprengel C, Probert I, Ostergaard J (2003) A guide to extant coccolithophore taxonomy. J Nannoplankt Res Special Issue 1:1-132

Young JR, Ziveri P (2000) Calculation of coccolith volume and its use in calibration of carbonate flux estimates. Deep-Sea Res Pt II 47:1679-1700

Ziveri P, Broerse ATC, van Hinte JE, Westbroek P, Honjo S (2000) The fate of coccoliths at $48^{\circ} \mathrm{N} 21^{\circ} \mathrm{W}$, northeastern Atlantic. Deep-Sea Res Pt II 47:1853-1875

Ziveri P, de Bernardi B, Baumann KH, Stoll HM, Mortyn PG (2007) Sinking of coccolith carbonate and potential contribution to organic carbon ballasting in the deep ocean. Deep-Sea Res Pt II 54:659-675

Zondervan I (2007) The effects of light, macronutrients, trace metals and $\mathrm{CO}_{2}$ on the production of calcium carbonate and organic carbon in coccolithophores-A review. Deep-Sea Res Pt II 54:521-537 
723 Table 1: Coccolith shape factors, coccolith calcite, coccoliths per cell and cellular calcite for the individual coccolithophore species.

724

\begin{tabular}{|c|c|c|c|c|}
\hline Species & $\begin{array}{l}\text { Coccolith Shape } \\
\text { Factor }\left(\mathrm{k}_{\mathrm{s}}\right) \\
\end{array}$ & $\begin{array}{c}\text { Coccolith Calcite } \\
\text { (pmol) }\end{array}$ & Coccoliths per Cell & $\begin{array}{c}\text { Cellular Calcite } \\
\text { (pmol) }\end{array}$ \\
\hline E. huxleyi & 0.020 & 0.024 & 22 & 0.52 \\
\hline C. pelagicus & 0.060 & 1.218 & 13 & 15.2 \\
\hline Syracosphaera spp. & 0.015 & 0.012 & 35 & 0.40 \\
\hline A. quattrospina & 0.030 & 0.008 & 36 & 0.27 \\
\hline C. caudatus & 0.013 & 0.002 & 54 & 0.09 \\
\hline Ophiaster sp. & 0.035 & 0.001 & 70 & 0.09 \\
\hline A. robusta & 0.045 & 0.010 & 43 & 0.42 \\
\hline C. pelagicus HOL & 0.036 & 0.008 & 100 & 0.78 \\
\hline
\end{tabular}


727 Table 2: Physicochemical features: $\mathrm{Z}_{\text {eup }}$, euphotic depth; $\Omega_{\mathrm{C}}$, calcite saturation state; $\mathrm{NO}_{\mathrm{x}}$, nitrate + nitrite; $\mathrm{PO}_{4}$, phosphate; $\mathrm{dSi}$, silicic acid; $\mathrm{N}^{*}$, 728 excess $\mathrm{NO}_{\mathrm{x}}$ relative to $\mathrm{PO}_{4}$; $\mathrm{Si}^{*}$, excess dSi to $\mathrm{NO}_{\mathrm{x}}$.

\begin{tabular}{|c|c|c|c|c|c|c|c|c|c|c|c|c|c|c|c|c|c|}
\hline \multirow[b]{2}{*}{ CTD } & \multirow[b]{2}{*}{ Location } & \multirow[b]{2}{*}{$\begin{array}{l}\text { Lat } \\
\left({ }^{\circ} \mathrm{N}\right)\end{array}$} & \multirow[b]{2}{*}{$\begin{array}{l}\text { Lon } \\
\left({ }^{\circ} \mathrm{E}\right)\end{array}$} & \multirow[b]{2}{*}{ Date } & \multirow[b]{2}{*}{$\begin{array}{l}\text { Depth } \\
(\mathrm{m})\end{array}$} & \multirow[b]{2}{*}{$\begin{array}{l}\text { Temperature } \\
\left({ }^{\circ} \mathrm{C}\right)\end{array}$} & \multirow[b]{2}{*}{ Salinity } & \multirow[b]{2}{*}{$\begin{array}{c}\text { Daily PAR } \\
\text { (mol photons } \\
\left.\mathrm{m}^{-2} \mathrm{~d}^{-1}\right) \\
\end{array}$} & \multirow[b]{2}{*}{$\begin{array}{l}Z_{\text {eup }} \\
(\mathrm{m})\end{array}$} & \multicolumn{3}{|c|}{ Carbonate Chemistry } & \multicolumn{5}{|c|}{$\begin{array}{l}\text { Surface Macronutrients } \\
\left(\mathrm{mmol} \mathrm{m}^{-3}\right)\end{array}$} \\
\hline & & & & & & & & & & $\begin{array}{c}\mathrm{pCO}_{2} \\
\text { ( } \mu \text { atm) }\end{array}$ & $\mathrm{pH}_{\mathrm{T}}$ & $\Omega_{\mathrm{C}}$ & $\mathrm{NO}_{\mathrm{x}}$ & $\mathrm{PO}_{4}$ & $\mathrm{dSi}$ & $\mathrm{N}^{*}$ & $\mathrm{Si}^{*}$ \\
\hline 6 & ICB & 58.74 & -0.86 & 04 Jun & 9 & 10.0 & 35.3 & 45 & 40 & 277 & 8.2 & 4.2 & 0.5 & 0.11 & 1.7 & -1.3 & -1.2 \\
\hline 8 & ICB & 60.13 & -6.71 & 05 Jun & 10 & 10.4 & 35.4 & 33 & 48 & 326 & 8.1 & 3.8 & 6.5 & 0.45 & 4.3 & -0.7 & 2.3 \\
\hline 10 & ICB & 59.97 & -11.98 & 06 Jun & 20 & 10.6 & 35.3 & 51 & 28 & 310 & 8.1 & 4.0 & 2.9 & 0.21 & 1.4 & -0.4 & 1.5 \\
\hline 12 & ICB & 60.00 & -18.67 & 07 Jun & 10 & 10.2 & 35.2 & 41 & 37 & 340 & 8.1 & 3.7 & 6.1 & 0.4 & 1.7 & -0.3 & 4.4 \\
\hline 17 & ICB & 60.59 & -18.86 & 08 Jun & 20 & 10.4 & 35.2 & 10 & 40 & 310 & 8.1 & 3.9 & 5.2 & 0.35 & 1.3 & -0.4 & 3.9 \\
\hline 19 & NWS & 65.98 & -10.72 & 09 Jun & 24 & 3.6 & 34.8 & 34 & 23 & 240 & 8.2 & 3.7 & 0.6 & 0.22 & 2.5 & -3.0 & -1.9 \\
\hline 20 & NWS & 69.90 & -7.58 & 10 Jun & 15 & 3.1 & 35.0 & 53 & 36 & 363 & 8.1 & 2.7 & 9.1 & 0.64 & 6.1 & -1.2 & 3.0 \\
\hline 21 & GS & 74.12 & -4.69 & 11 Jun & 15 & 1.0 & 34.9 & 40 & 48 & 308 & 8.1 & 2.8 & 9.8 & 0.7 & 5.7 & -1.4 & 4.0 \\
\hline 27 & GS & 76.18 & -2.55 & 12 Jun & 20 & 1.5 & 34.9 & 42 & 50 & 319 & 8.1 & 2.7 & 9.3 & 0.67 & 4.7 & -1.4 & 4.6 \\
\hline 29 & GS & 78.72 & 0.00 & 13 Jun & 10 & 3.5 & 35.0 & 51 & 15 & 209 & 8.3 & 4.1 & 2.6 & 0.31 & 5.5 & -2.4 & -2.9 \\
\hline 40 & GS & 78.25 & -5.55 & 14 Jun & 15 & 3.1 & 34.9 & 20 & 25 & 309 & 8.1 & 3.0 & 8.7 & 0.62 & 5.6 & -1.2 & 3.1 \\
\hline 42 & NWS & 78.22 & -6.00 & 15 Jun & 15 & 6.0 & 35.1 & 28 & 22 & 208 & 8.3 & 4.5 & 4.0 & 0.38 & 4.3 & -2.1 & -0.4 \\
\hline 45 & NWS & 77.82 & -4.97 & 16 Jun & 20 & 5.7 & 35.2 & 19 & 41 & 309 & 8.1 & 3.3 & 9.8 & 0.72 & 5.8 & -1.8 & 4.0 \\
\hline 54 & NWS & 77.85 & -1.29 & 17 Jun & 13 & 7.8 & 35.0 & 24 & 41 & 320 & 8.1 & 3.5 & 6.0 & 0.49 & 3.8 & -1.8 & 2.2 \\
\hline 56 & NWS & 78.99 & 7.98 & 18 Jun & 15 & 6.7 & 35.2 & 33 & 31 & 305 & 8.1 & 3.5 & 6.8 & 0.5 & 5.2 & -1.2 & 1.6 \\
\hline 58 & NWS & 76.26 & 12.54 & 19 Jun & 20 & 5.4 & 35.1 & 35 & 38 & 316 & 8.1 & 3.2 & 10.6 & 0.77 & 5.7 & -1.7 & 4.9 \\
\hline 60 & GS & 76.16 & 23.07 & 20 Jun & 26 & 1.4 & 34.7 & 49 & 45 & 328 & 8.1 & 2.6 & 8.6 & 0.64 & 2.2 & -1.6 & 6.5 \\
\hline 63 & NWS & 72.89 & 26.00 & 22 Jun & 20 & 3.8 & 34.8 & 40 & 32 & 318 & 8.1 & 3.0 & 8.9 & 0.65 & 2.6 & -1.5 & 6.3 \\
\hline 65 & NWS & 71.75 & 17.90 & 23 Jun & 20 & 5.1 & 34.9 & 33 & 48 & 246 & 8.2 & 3.8 & 4.0 & 0.43 & 4.1 & -2.8 & 0.0 \\
\hline
\end{tabular}


Table 3: Coccolithophore abundances (cells $\mathrm{mL}^{-1}$ )

\begin{tabular}{|c|c|c|c|c|c|c|c|c|c|}
\hline \multirow[b]{2}{*}{ CTD } & \multirow[b]{2}{*}{ Location } & \multicolumn{8}{|c|}{ Coccolithophore abundance (cells $\mathrm{mL}^{-1}$ ) } \\
\hline & & E. huxleyi & C. pelagicus & C. pelagicus HOL & Syracosphaera spp. & A. quattrospina & C. caudatus & Ophiaster sp. & A. robusta \\
\hline 6 & ICB & 31.7 & - & - & - & 1.5 & - & - & - \\
\hline 8 & ICB & 21.2 & 2.6 & - & 24.2 & - & 3.0 & 1.5 & 3.0 \\
\hline 10 & ICB & 64.1 & 2.3 & 3.0 & 7.9 & 2.4 & 0.6 & 2.4 & - \\
\hline 12 & ICB & 76.2 & 7.7 & - & 179.6 & 10.9 & 348.3 & 27.2 & - \\
\hline 17 & ICB & 91.2 & 4.2 & 5.4 & 84.4 & 12.2 & 179.6 & 50.3 & - \\
\hline 19 & NWS & 1.9 & 2.8 & - & - & - & - & - & - \\
\hline 20 & NWS & - & 0.6 & 59.9 & - & - & 359.2 & - & 5.4 \\
\hline 21 & GS & - & 0.4 & 3.8 & - & - & - & - & - \\
\hline 27 & GS & - & - & 6.0 & - & - & - & - & - \\
\hline 29 & GS & 17.0 & 0.4 & 0.9 & - & - & - & - & 0.9 \\
\hline 40 & GS & 1.9 & - & 11.3 & - & - & - & - & - \\
\hline 42 & NWS & 25.2 & - & - & - & - & - & - & - \\
\hline 45 & NWS & 69.5 & 0.1 & 1.5 & - & - & 1.5 & - & 4.5 \\
\hline 54 & NWS & 19.7 & - & - & - & - & - & - & 4.5 \\
\hline 56 & NWS & 424.5 & 7.1 & 223.1 & - & - & 157.8 & - & 119.7 \\
\hline 58 & NWS & 33.1 & 15.4 & 2.2 & - & - & 72.8 & - & 47.4 \\
\hline 60 & GS & - & 2.8 & 54.8 & - & - & - & - & - \\
\hline 63 & NWS & 20.8 & 32.7 & - & - & - & 274.0 & - & - \\
\hline 65 & NWS & 2.8 & 2.9 & - & - & - & - & - & - \\
\hline
\end{tabular}




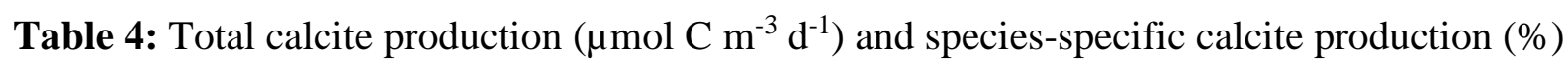

\begin{tabular}{|c|c|c|c|c|c|c|c|c|c|c|}
\hline \multirow[b]{2}{*}{ CTD } & \multirow[b]{2}{*}{ Location } & \multirow[b]{2}{*}{ 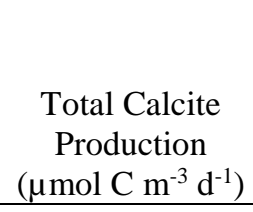 } & \multicolumn{8}{|c|}{ \% Calcite Production } \\
\hline & & & $\begin{array}{c}\text { E. } \\
\text { huxleyi }\end{array}$ & $\begin{array}{c}\text { C. } \\
\text { pelagicus }\end{array}$ & $\begin{array}{c}\text { C. pelagicus } \\
\text { HOL }\end{array}$ & $\begin{array}{c}\text { Syracosphaera } \\
\text { spp. }\end{array}$ & $\begin{array}{c}\text { A. } \\
\text { quattrospina }\end{array}$ & $\begin{array}{c}\text { C. } \\
\text { caudatus }\end{array}$ & $\begin{array}{l}\text { Ophiaster } \\
\text { sp. }\end{array}$ & $\begin{array}{c}\text { A. } \\
\text { robusta }\end{array}$ \\
\hline 6 & ICB & 7.25 & 97.6 & - & - & - & 2.4 & - & - & - \\
\hline 8 & ICB & 21.65 & 17.7 & 64.1 & - & 15.5 & - & 0.5 & 0.2 & 2.0 \\
\hline 10 & ICB & 7.06 & 44.4 & 47.1 & 3.1 & 4.2 & 0.9 & 0.1 & 0.3 & - \\
\hline 12 & ICB & 42.51 & 14.9 & 43.9 & - & 27.0 & 1.1 & 12.3 & 0.9 & - \\
\hline 17 & ICB & 13.56 & 27.2 & 37.0 & 2.4 & 19.3 & 1.9 & 9.7 & 2.5 & - \\
\hline 19 & NWS & 11.31 & 2.3 & 97.7 & - & - & - & - & - & - \\
\hline 20 & NWS & 17.45 & - & 9.8 & 50.8 & - & - & 36.8 & - & 2.5 \\
\hline 21 & GS & 1.65 & - & 70.0 & 30.0 & - & - & - & - & - \\
\hline 27 & GS & 3.54 & - & - & 100.0 & - & - & - & - & - \\
\hline 29 & GS & 9.04 & 54.8 & 38.2 & 4.5 & - & - & - & - & 2.5 \\
\hline 40 & GS & 29.64 & 10.0 & - & 90.0 & - & - & - & - & - \\
\hline 42 & NWS & 18.96 & 100.0 & - & - & - & - & - & - & - \\
\hline 45 & NWS & 16.69 & 88.6 & 3.5 & 2.9 & - & - & 0.3 & - & 4.7 \\
\hline 54 & NWS & 8.61 & 84.2 & - & - & - & - & - & - & 15.8 \\
\hline 56 & NWS & 63.93 & 38.9 & 19.0 & 30.5 & - & - & 2.6 & - & 8.9 \\
\hline 58 & NWS & 201.55 & 6.2 & 83.6 & 0.6 & - & - & 2.4 & - & 7.1 \\
\hline 60 & GS & 16.21 & - & 50.3 & 49.7 & - & - & - & - & - \\
\hline 63 & NWS & 55.87 & 2.0 & 93.2 & - & - & - & 4.8 & - & - \\
\hline 65 & NWS & 29.58 & 3.2 & 96.8 & - & - & - & - & - & - \\
\hline
\end{tabular}


Table 5: Results of the principal component analysis (PCA), including eigenvectors and Pearson correlations coefficients for the relationships between PC scores, environmental variables and individual species contributions to both species composition and $\mathrm{CP}_{\text {sp. }}{ }^{* * *} p<$

\begin{tabular}{|c|c|c|}
\hline \multirow[t]{2}{*}{ Variables } & \multicolumn{2}{|c|}{ Variables vs. principal components } \\
\hline & PC-1 (40.1 \%) & PC-2 (33.3 \%) \\
\hline \multicolumn{3}{|l|}{ Environmental } \\
\hline Temperature & $0.23(0.41)$ & $0.53(\mathbf{0 . 8 7 * * *})$ \\
\hline Salinity & $0.19(0.34)$ & $0.53(\mathbf{0 . 8 7 * * *})$ \\
\hline$\Omega_{\mathrm{C}}$ & $0.51(\mathbf{0 . 9 2 * * *})$ & $0.21(0.34)$ \\
\hline $\mathrm{pH}_{\mathrm{T}}$ & $0.48(\mathbf{0 . 8 7 * * *})$ & $-0.26(-0.42)$ \\
\hline $\mathrm{N}^{*}$ & $-0.19(-0.35)$ & $0.51(\mathbf{0 . 8 3} * * *)$ \\
\hline $\mathrm{Si}^{*}$ & $-0.50(-0.90 * * *)$ & $0.12(0.19)$ \\
\hline PAR & $-0.06(-0.12)$ & $-0.14(-0.22)$ \\
\hline$Z_{\text {eup }}$ & $-0.35(-0.62 * * *)$ & $0.17(0.27)$ \\
\hline Latitude & -0.08 & $-0.68 * * *$ \\
\hline Longitude & 0.16 & -0.12 \\
\hline \multicolumn{3}{|l|}{ Species Composition } \\
\hline E. huxleyi & $0.85^{* * *}$ & 0.20 \\
\hline C. pelagicus & 0.12 & -0.43 \\
\hline C. pelagicus HOL & $-0.60 * *$ & -0.32 \\
\hline Syracosphaera spp. & 0.04 & $0.78^{* * *}$ \\
\hline A. quattrospina & 0.24 & $0.66^{* * *}$ \\
\hline C. caudatus & -0.35 & 0.32 \\
\hline Ophiaster sp. & 0.06 & $0.75^{* * *}$ \\
\hline A. robusta & 0.02 & 0.13 \\
\hline \multicolumn{3}{|l|}{$\% \mathrm{CP}_{\mathrm{sp}}$} \\
\hline E. huxleyi & $0.67^{* * *}$ & 0.37 \\
\hline C. pelagicus & -0.08 & -0.12 \\
\hline C. pelagicus HOL & $-0.57 *$ & -0.27 \\
\hline Syracosphaera spp. & 0.02 & $0.75^{* * *}$ \\
\hline A. quattrospina & 0.22 & $0.66^{* * *}$ \\
\hline C. caudatus & -0.32 & 0.31 \\
\hline Ophiaster sp. & 0.04 & $0.69^{* * *}$ \\
\hline A. robusta & -0.00 & 0.12 \\
\hline
\end{tabular}


743 Table 6: Spearman's rank correlation $\left(\mathrm{r}_{\mathrm{s}}\right)$ of environmental variables with coccolithophore species composition and species-specific calcite production $\left(\mathrm{CP}_{\mathrm{sp}}\right)$.

\begin{tabular}{llll}
\hline \multicolumn{2}{l}{ Coccolithophore species composition } & \multicolumn{2}{l}{ Species-specific calcite production $\left(\% \mathrm{CP}_{\mathrm{sp}}\right)$} \\
\hline Environmental variables & $\mathrm{r}_{\mathrm{s}}(p<0.01)$ & Environmental variables & $\mathrm{r}_{\mathrm{s}}(p<0.03)$ \\
\hline Temperature, $\Omega_{\mathrm{C}}, \mathrm{N}^{*}$ & 0.553 & $\Omega_{\mathrm{C}}$ & 0.368 \\
Temperature, $\Omega_{\mathrm{C}}$ & 0.553 & Temperature, $\Omega_{\mathrm{C}}$ & 0.308 \\
$\Omega_{\mathrm{C}}$ & 0.546 & $\Omega_{\mathrm{C}}$ PAR & 0.256 \\
\hline
\end{tabular}

745 


\section{Figure Captions}

749 Fig. 1: Sampling locations in the Iceland Basin (triangles), the Norwegian Sea (black filled 750 circles) and the Greenland Sea (white open circles). (A) Sea ice concentration (\%) in June

751 2012, taken from www.nsidc.org. (B) MODIS sea surface temperature for June 2012, 752 overlaid with the East Greenland Current (EGC) and the Norwegian Current (NC).

753 Fig. 2: SEM images. (A) Emiliania huxleyi. (B) Coccolithus pelagicus. (C) Coccolithus 754 pelagicus HOL. (D) Calciopappus caudatus. (E) Syracosphaera molischii. (F) Algirosphaera 755 robusta. Scale bars represent $1 \mu \mathrm{m}$.

756 Fig. 3: The distribution of total calcite production $\left(\mu \mathrm{mol} \mathrm{C} \mathrm{m} \mathrm{m}^{-3} \mathrm{~d}^{-1}\right)$.

757 Fig. 4: The distribution of species-specific calcite production ( $\left.\mu \mathrm{mol} \mathrm{C} \mathrm{m} \mathrm{m}^{-3} \mathrm{~d}^{-1}\right)$. (A) Emiliania 758 huxleyi. (B) Coccolithus pelagicus C) Coccolithus pelagicus HOL D) Other coccolithophore 759 species.

760 Fig. 5: The percentage contribution of coccolithophore species to (A) abundance and (B) 761 calcite production, aggregated over each hydrographic region and the entire study area.

762 Fig. 6: Non-metric multidimensional scaling (NMDS) ordination of (A, B, C and D) 763 coccolithophore species composition and (E, F, G and H) species-specific calcite production 764 based on Bray-Curtis similarity. Plots (A) and (E) are labelled according to the hydrographic 765 province of the stations. Plots (B), (C) and (D) are overlaid with bubble plots of the 766 composition of (B) Emiliania huxleyi, (C) Coccolithus pelagicus, and (D) Coccolithus 767 pelagicus HOL. Plots (E), (F) and (G) are overlaid with bubble plots of the species-specific 768 calcite production of (F) Emiliania huxleyi, (G) Coccolithus pelagicus, and (H) Coccolithus 769 pelagicus HOL.

$770 \quad$ Fig. 7: The effect of varying the relative growth rate of one species on the species 771 contribution to calcite production. The growth rates of (A) Emiliania huxleyi, (B) Coccolithus 772 pelagicus, and (C) Coccolithus pelagicus HOL were singly varied whilst all other species had 773 a relative growth rate of $100 \%$. (D) The relative growth rate of Coccolithus pelagicus was 774 varied, whilst Emiliania huxleyi had a relative growth rate of $200 \%$ and other species $100 \%$. 775 
Fig. 1
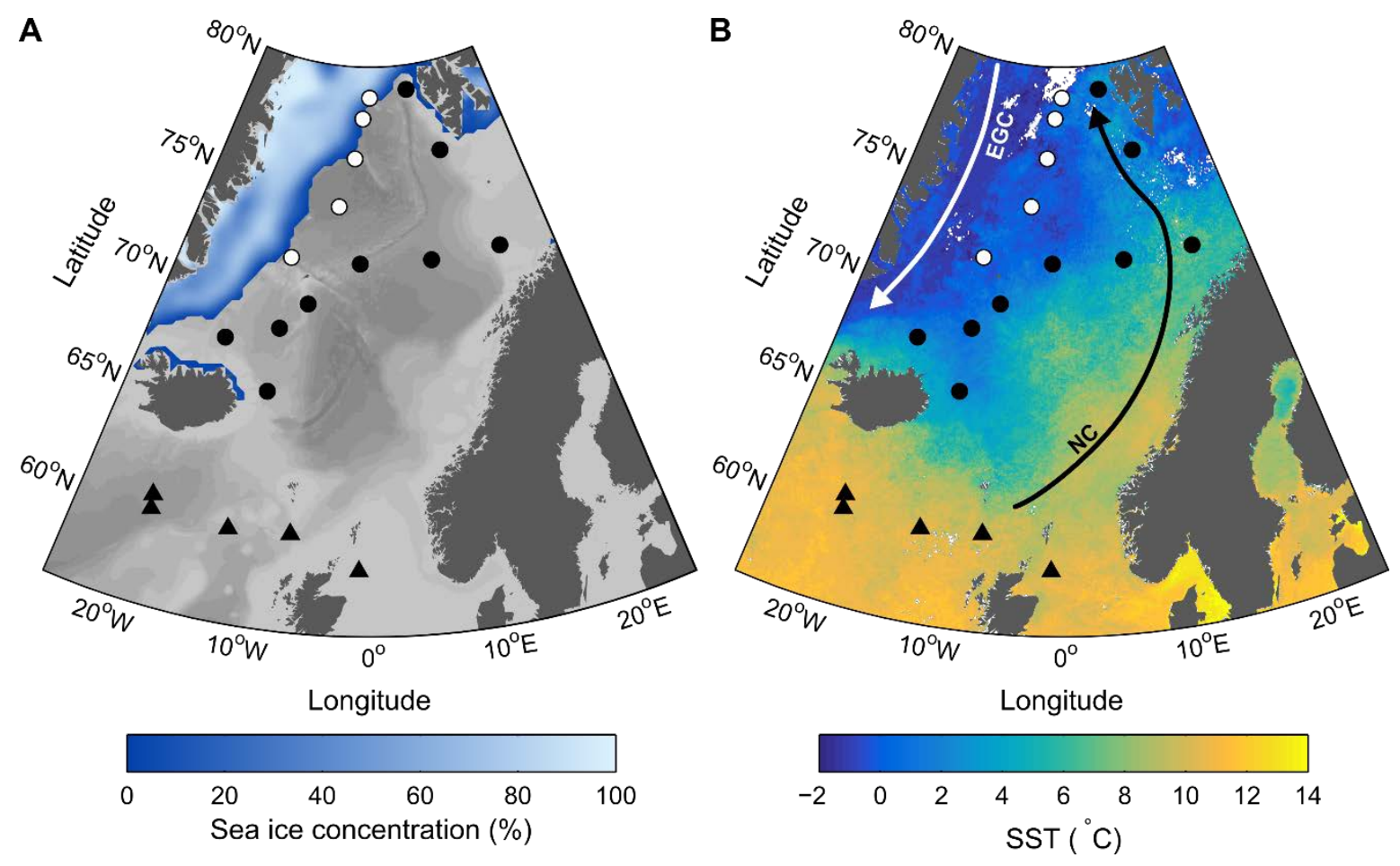

777 
$779 \quad$ Fig. 2

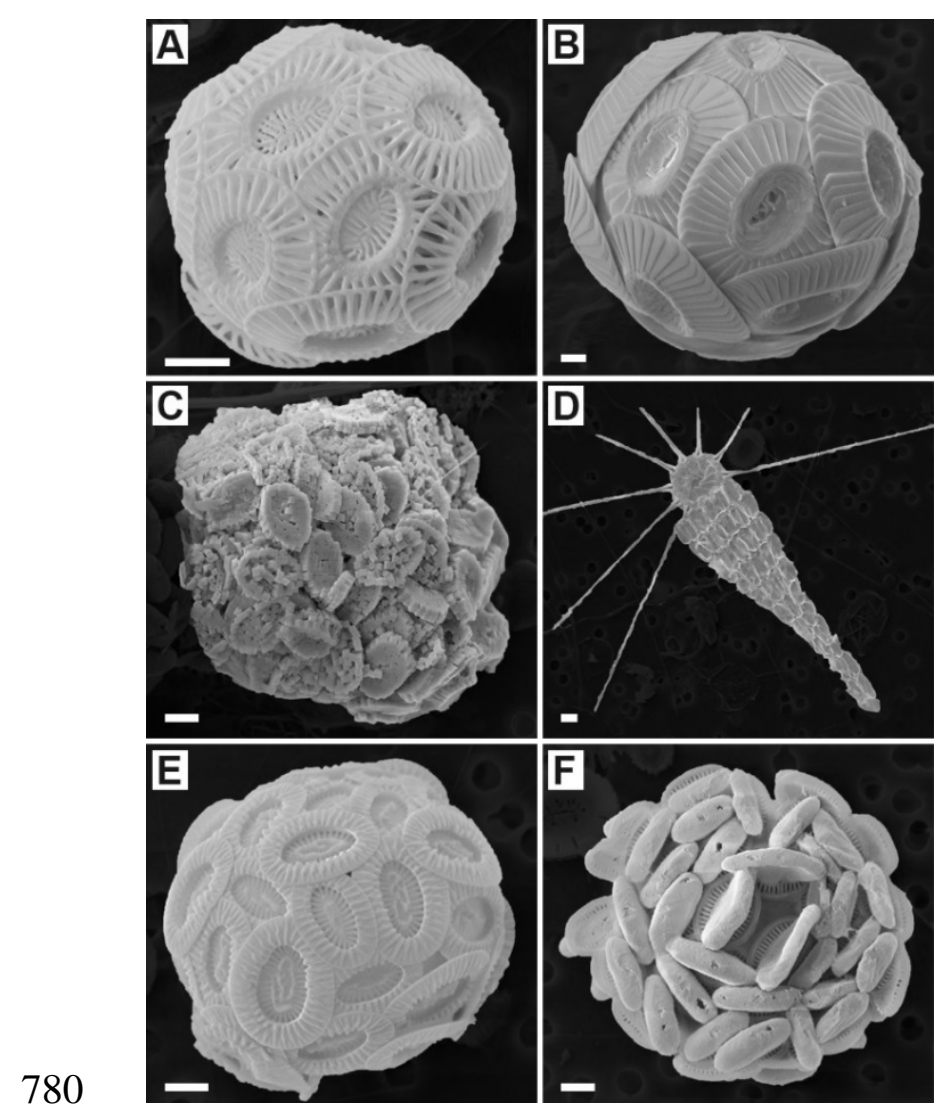

781 
Fig. 3

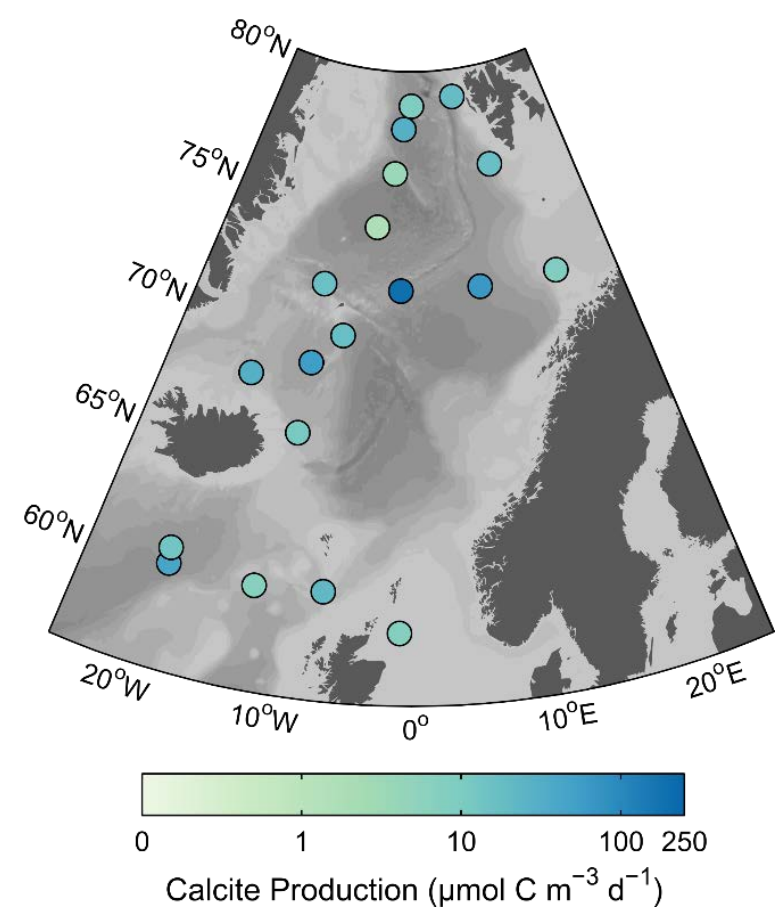


Fig. 4
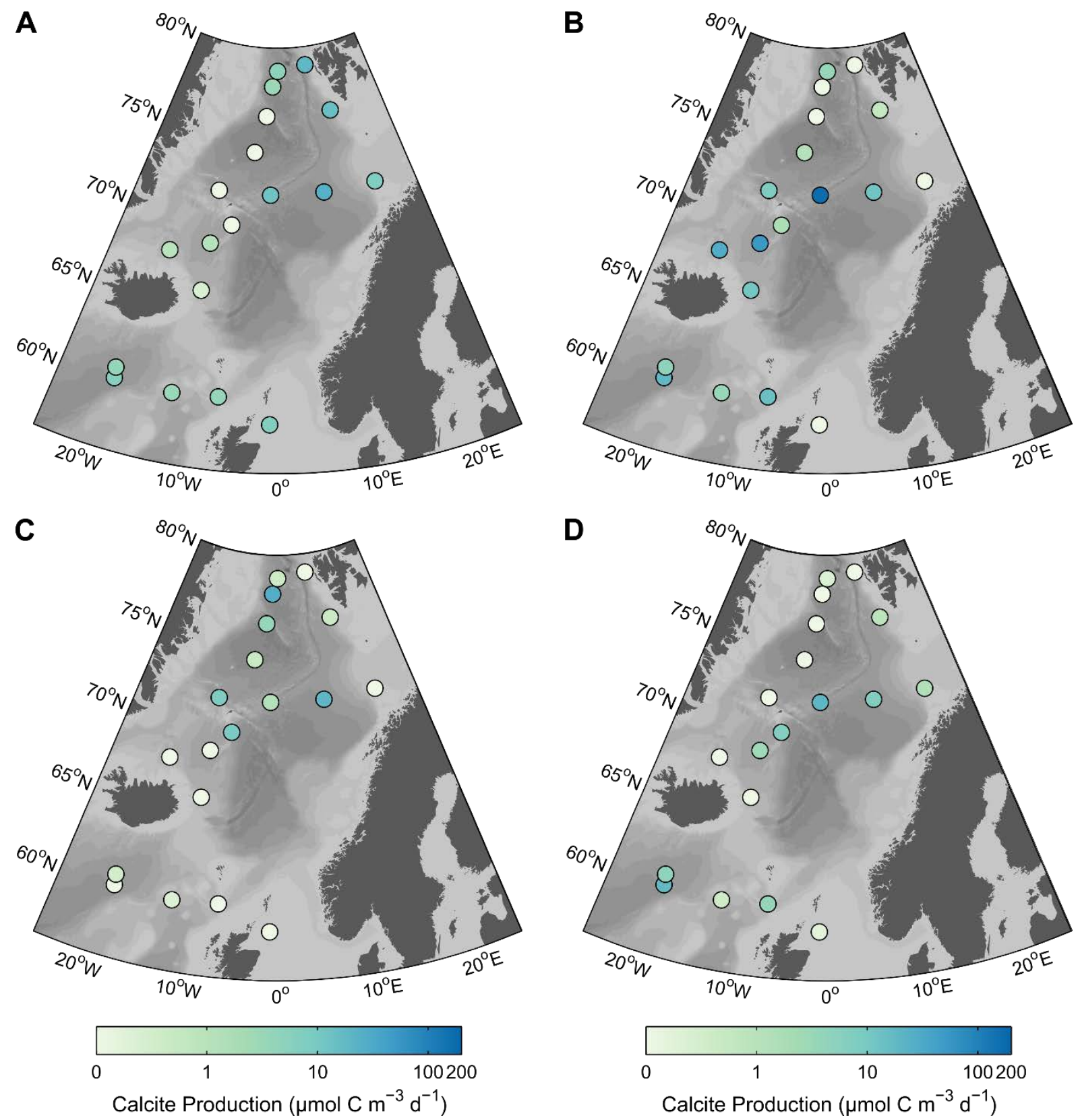
Calcite Production ( $\mu \mathrm{mol} \mathrm{C} \mathrm{m}{ }^{-3} \mathrm{~d}^{-1}$ ) 
Fig. 5

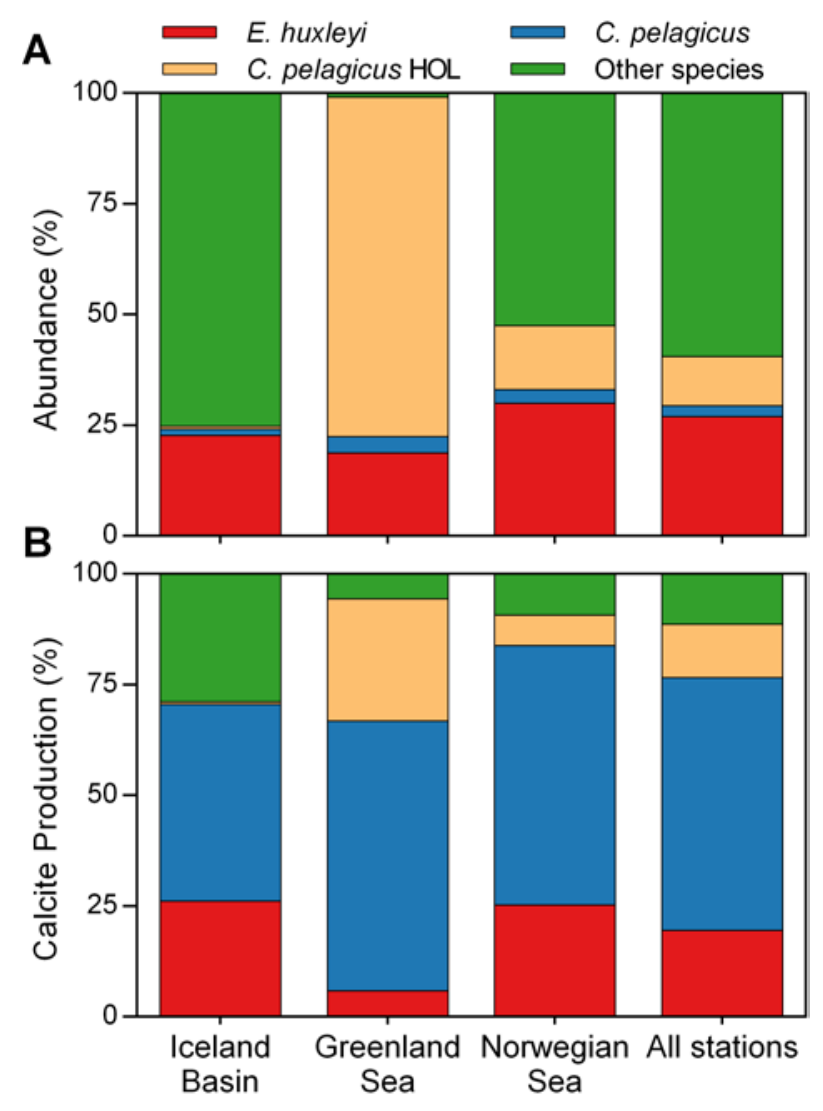


$789 \quad$ Fig. 6

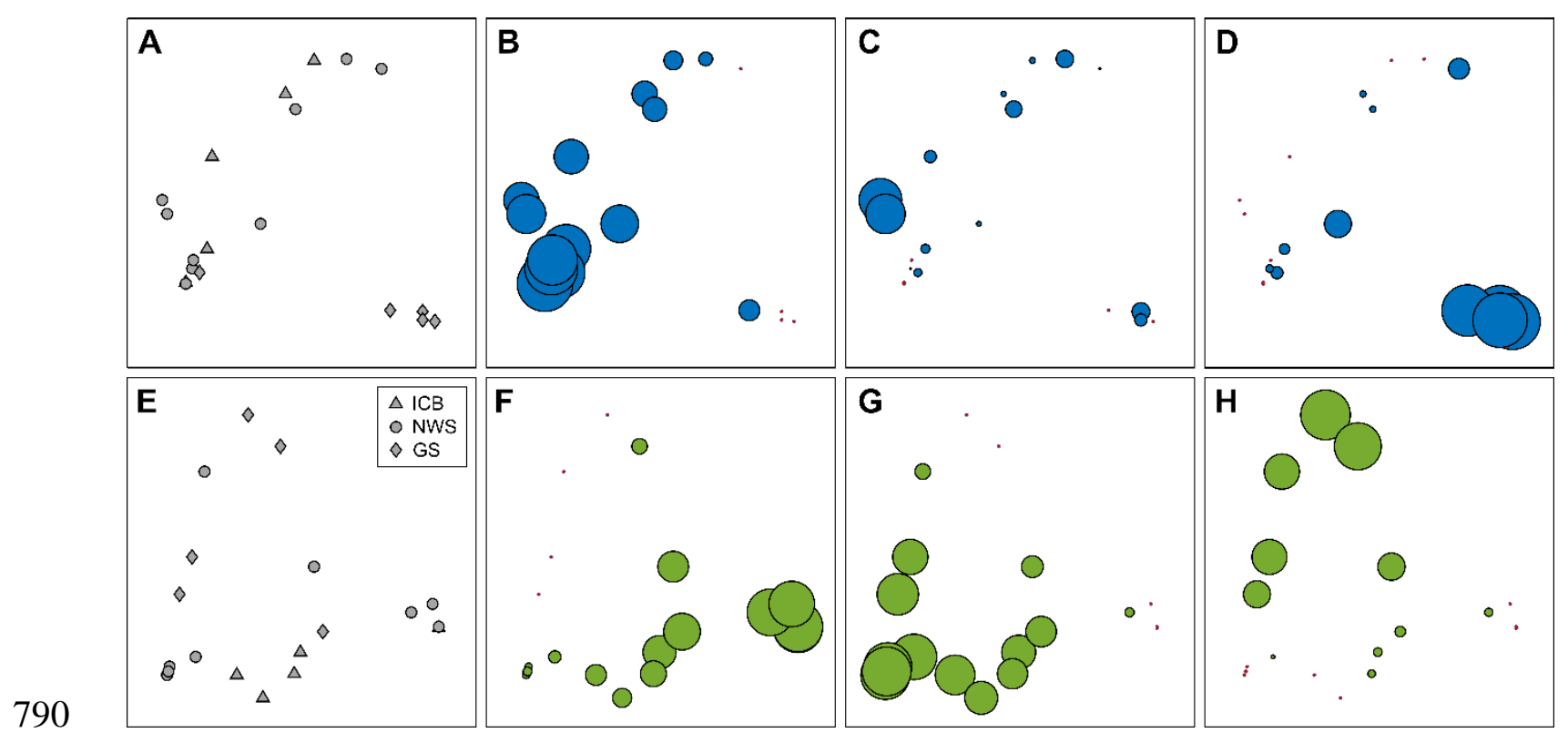

791 
Fig. 7
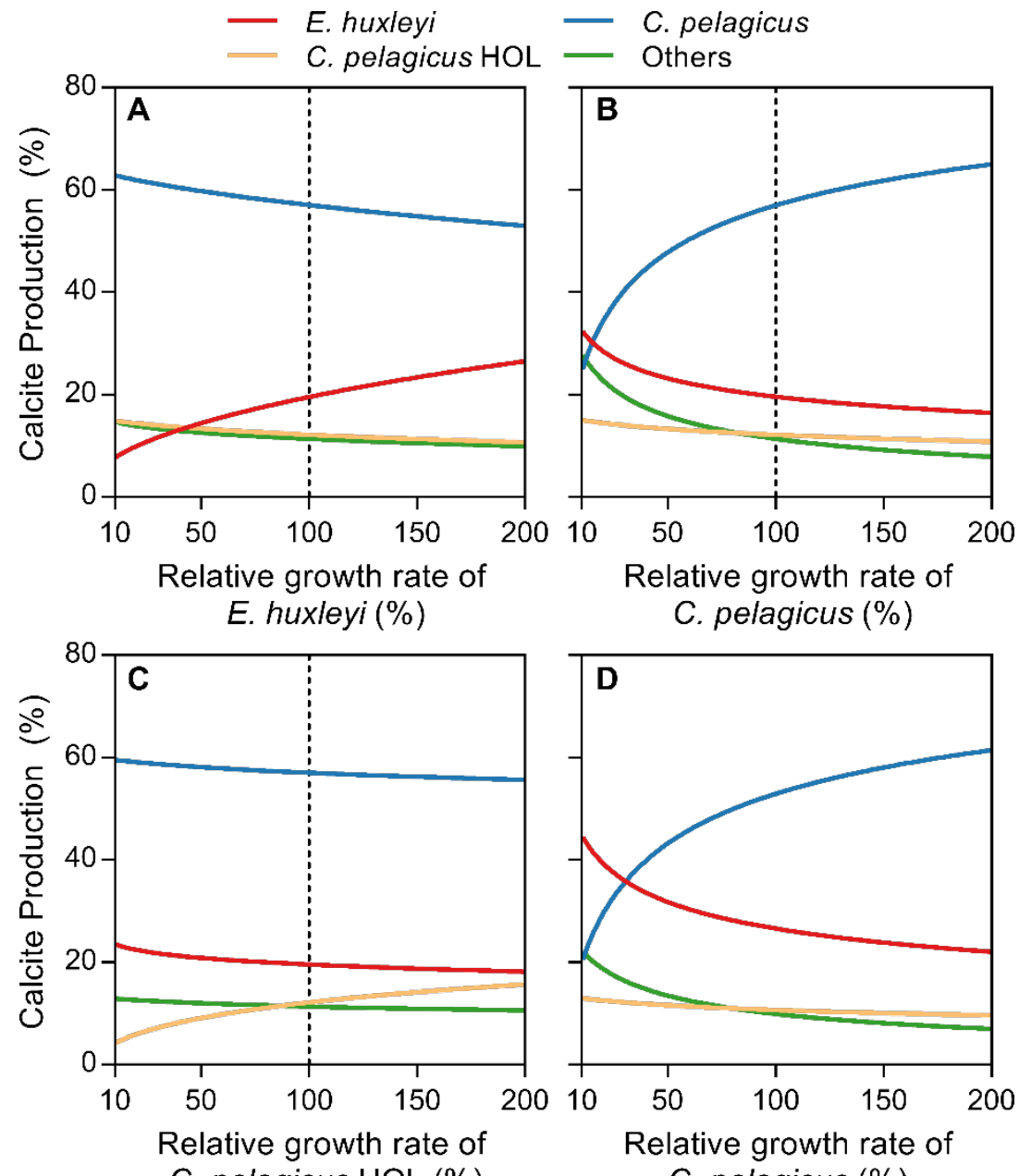

C. pelagicus (\%)

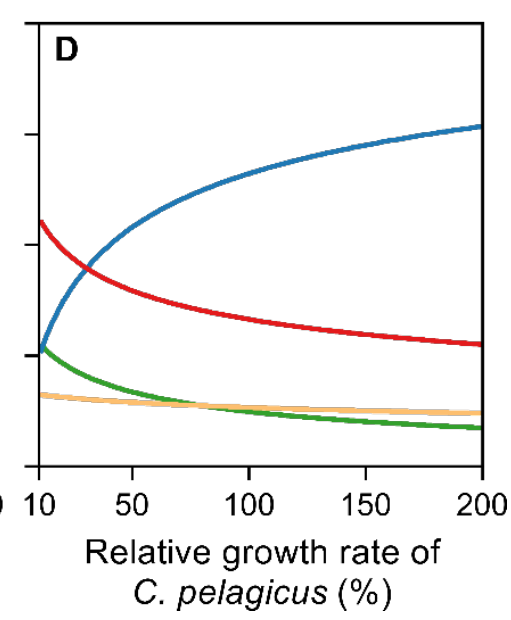

